\title{
Building WF16: construction of a PPNA pisé structure in Southern Jordan
}

\author{
Article \\ Published Version \\ Creative Commons: Attribution 3.0 (CC-BY)
}

Flohr, P., Finlayson, B., Najjar, M. and Mithen, S. (2015) Building WF16: construction of a PPNA pisé structure in Southern Jordan. Levant, 47 (2). pp. 143-163. ISSN 00758914 doi: https://doi.org/10.1179/0075891415Z.00000000063 Available at https://centaur.reading.ac.uk/40354/

It is advisable to refer to the publisher's version if you intend to cite from the work. See Guidance on citing.

To link to this article DOI: http://dx.doi.org/10.1179/0075891415Z.00000000063

Publisher: Maney Publishing

All outputs in CentAUR are protected by Intellectual Property Rights law, including copyright law. Copyright and IPR is retained by the creators or other copyright holders. Terms and conditions for use of this material are defined in the End User Agreement.

\section{www.reading.ac.uk/centaur}

\section{CentAUR}

Central Archive at the University of Reading

Reading's research outputs online 


\title{
Building WF16: construction of a Pre-Pottery Neolithic A (PPNA) pisé structure in Southern Jordan
}

\author{
Pascal Flohr ${ }^{1}$, Bill Finlayson², Mohammad Najjar ${ }^{2}$ and Steven Mithen ${ }^{3}$
}

The Pre-Pottery Neolithic A (PPNA) period in South-west Asia is essential for our understanding of the transition to sedentary, agricultural communities. Developments in architecture are key to understanding this transition, but many aspects of PPNA architecture remain elusive, such as construction techniques, the selection of building materials and the functional use of space. The primary aim of the research described within this contribution was to build a PPNA-like structure in order to answer questions about PPNA architecture in general, while specifically addressing issues raised by the excavation of structures at the site of WF16, southern Jordan. The second aim was to display a 'PPNA' building to visitors in Wadi Faynan to enhance their understanding of the period. The experimental construction based on one of the WF16 structures showed that (1) required materials can be acquired locally; (2) a construction technique using mud layers as described in this paper was most probably used; (3) flat, or very slightly dome-shaped, roofs are functional and can also be used as a solid working platform; (4) the WF16 small semisubterranean buildings appear inappropriate for housing a nuclear family unit.

Keywords Pre-Pottery Neolithic A, Wadi Faynan, Jordan, experimental archaeology, architecture

\section{Introduction}

Excavations (2008-10) at the Pre-Pottery Neolithic A (PPNA) site WF16 in southern Jordan (Figs 1, 2), currently dated to $c .11,600-10,200 \mathrm{cal} \mathrm{BP}$ (Mithen and Finlayson 2007), uncovered a range of structures (Figs 2, 3). Most of these are 'typical' for the period: relatively small, semi-subterranean, elliptical in shape, with mud wall lining and mud-plaster floors (Figs 3-5; Finlayson et al. 2011b). Other structures, however, provide novel architectural features for the PPNA, especially with regard to size and internal organization (Finlayson et al. 2011a; 2011b; Mithen et al. 2011). To gain further insight into various

'Department of Archaeology, University of Reading, Whiteknights, PO Box 227, Reading RG6 6AB, UK; ' Council for British Research in the Levant, 10 Carlton House Terrace, London SW1Y 5AH, UK; 'Vice Chancellor's Office, University of Reading, Whiteknights, PO Box 217, Reading RG6 6AH, UK

Pascal Flohr (corresponding author) Department of Archaeology, University of Reading, Whiteknights, PO Box 227, Reading RG6 6AB, UK. email: p.flohr@reading.ac.uk aspects of PPNA architecture and to present an example to both local and international visitors, a replica, better termed a 'construct' (Reynolds 1999: 159; Stone and Planel 1999: 1-2), of one of the WF16 structures was built in the autumn of 2010 .

Although the PPNA period in South-west Asia is recognized as being fundamental to our understanding of the transition to a sedentary agricultural society, numerous aspects of its architecture are poorly understood, notably the specifics of the construction techniques (Dennis et al. 2002). What kinds of materials were required and in what quantities? What construction techniques were used? How much time/labour was required? While the evidence available suggests flat roofs made of mud supported by reeds and wooden beams were used, clearly by the Pre-Pottery Neolithic B (PPNB) (Kinzel 2004; Purschwitz and Kinzel 2007), and as we argue below, probably in the PPNA at WF16, it is necessary to explore whether 


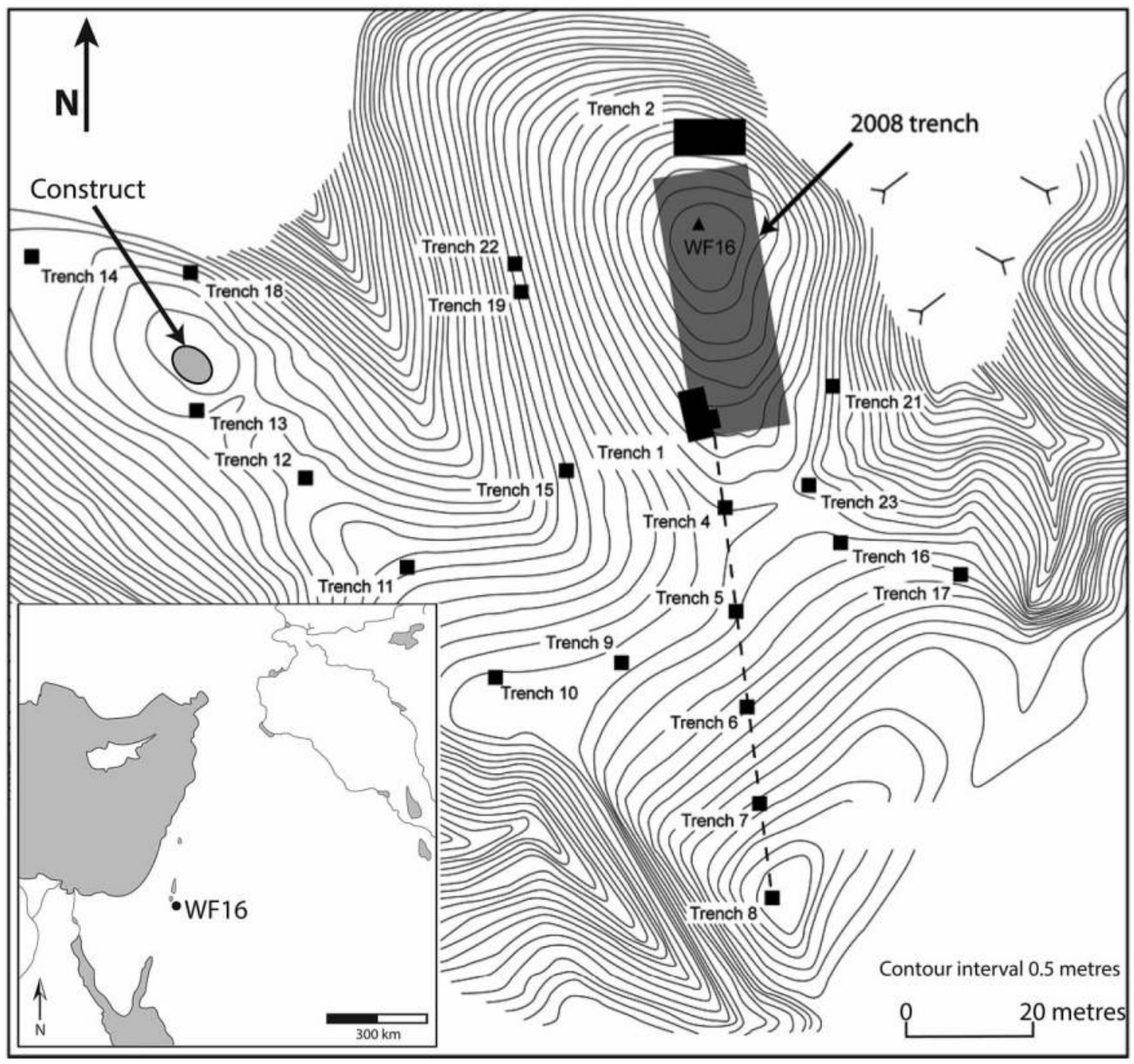

Figure 1 Location of Wadi Faynan, excavations at WF16, and the 'construct'.

such roofs would have been strong enough to carry people or potentially upper storeys. In addition, the maintenance and decay of PPNA buildings are of interest for understanding their potential longevity, which has a bearing on our ideas about sedentism and the interpretation of settlement data. Monitoring the decay of 'constructs' is essential for understanding archaeological site taphonomy; it is regrettable that, while most tell sites in the Near East consist in a large part of degraded building material, little is known about the degradation process itself (Friesem et al. 2011: 1135-36).

The primary objective in building a WF16 construct was to improve our understanding of PPNA earthen architecture. Although some experimental building of prehistoric structures has taken place in South-west Asia, such as at PPNB Beidha in Jordan (Dennis 2003a; 2003b; 2008; Dennis et al. 2002; Finlayson et al. 2003b), and Chalcolithic Lemba on Cyprus (Thomas 2005), no PPNA structures have been been reconstructed. The value of most of these existing experimental buildings for the PPNA is limited because of the use of wet applied mud (or pisé), rather than mudbrick within the PPNA period, as exemplified at WF16 (Watson (1979) provides an ethnographic account for the use of pisé and experimental work is described by Thomas (2005)).

The second objective of the current study was to present PPNA architecture to the wider public, both local residents and tourists visiting Wadi Faynan. The WF16 excavation trenches have been backfilled to protect the fragile archaeological remains; even if exposed these would be hard to interpret for most visitors. A construct can help people visualize what a PPNA building would have looked like. WF16 and its replica building are planned to form part of the Neolithic Heritage trail that is being established in the Greater Petra area in southern Jordan, together with the PPNB sites of Ghuwayr 1 (located just a few hundred metres from WF16), Basta, Beidha and Shkârat Msaied. 


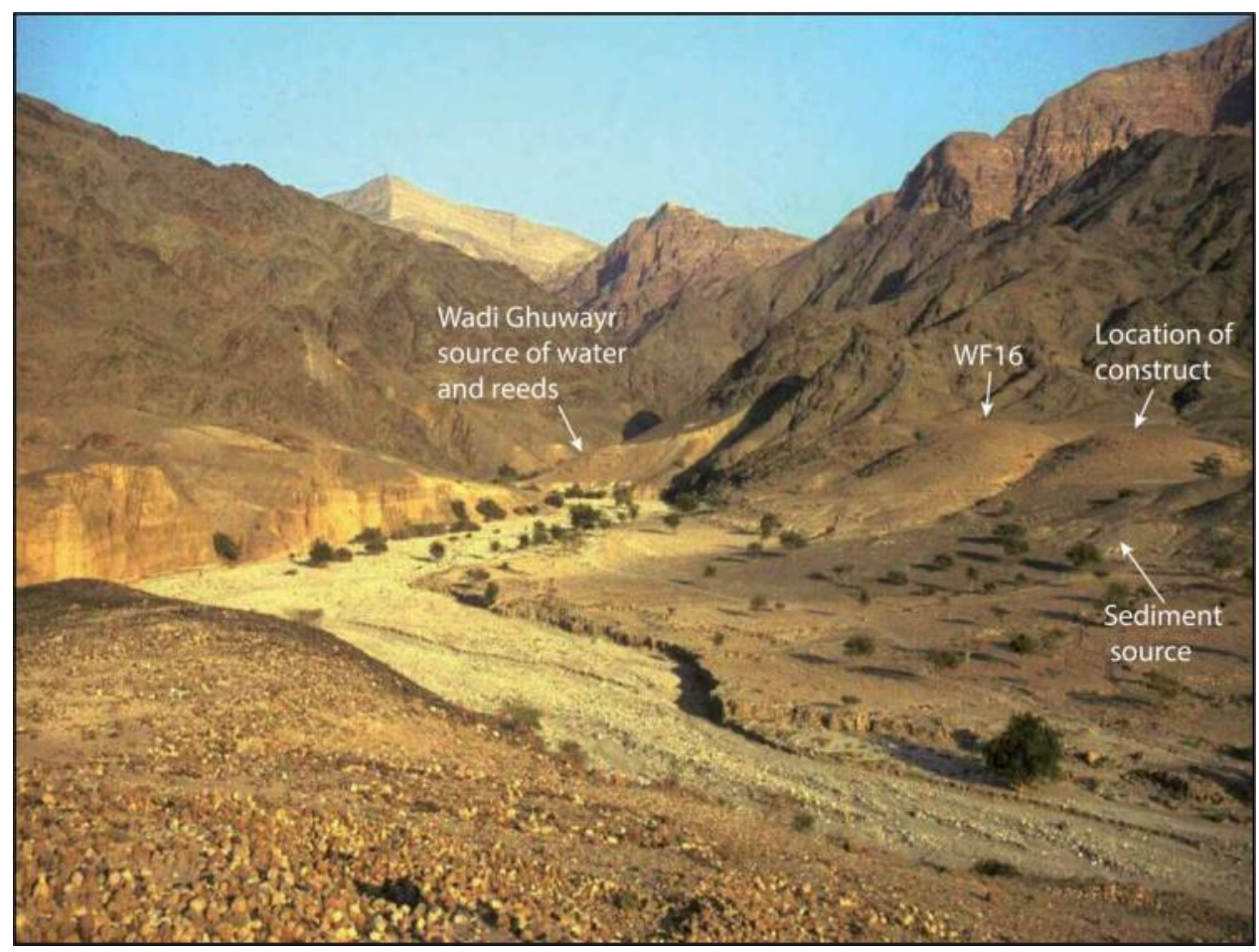

Figure 2 The juncture of Wadi Faynan and Wadi Ghuwayr, looking south-east. The further knoll on the left hand side of the image is the location of WF16, with the knoll to the right the setting for the construct.

Many 'reconstruction' projects are conducted to provide examples of past structures for the public and/or for educational purposes, in addition to the academic aims of experimental archaeology (Stone and Planel 1999). The combination of both the research and public archaeology objectives is important, because experimental archaeology, and especially the building of constructs, is often a compromise between the ideal requirements of the two aims (see Dennis 2003a; Stone and Planel 1999).

\section{Building with mud-a general introduction}

Sediment mixed with water and often with plant temper has been used as a building material since at least the Neolithic and remains widespread. Earthen buildings can be made from locally available materials, are relatively quick and easy to make, and are said to be cool in summer and warm in winter (Emery 2011: 1-2; Facey 1997; Fathy 1989; McHenry 1984). They are, however, vulnerable to decay, mainly due to water, and therefore need frequent maintenance (Emery 2011: 2).

In the Near East, the use of prefabricated, sun-dried mudbricks (or adobes) has been the most common method for constructing earthen buildings, but at several, especially Neolithic, sites, the mud appears to have been applied when wet (including at WF16, see below; e.g. Cauvin 1977; Kozlowski 1989: 27; Kozlowski and Kempisty 1990; Noy 1989; Samzun et al. 1989; Willcox and Fornite 1999). In Near
Eastern archaeology this is generally termed 'pisé', and involves building earthen walls by applying a mixture of sediment, water and often plant temper, in layers; each layer is allowed to dry before the next one is added on top. The term pisé is derived from the French pisé de terre, which refers to building with packed or rammed earth (Doat et al. 1979: fig. 2), while 'cob' is sometimes used for all forms of building for which earth was applied into a wall when still wet (Smith 2000). As such, the use of the term pise for applying (wet) layers of mud may not be completely correct (Thomas 2005: 5); nevertheless in this paper the term pisé will be adopted, following its conventional use in Near Eastern archaeology (e.g. Akkermans and Schwartz 2003; Newton 2004; Willcox and Fornite 1999), and considering the lack of a more suitable term. Examples of wet mud building techniques include applying layers on a wall and walking over it to compress the mud, applying smaller amounts of mud mix on a wall and shaping it by hand, as well as pre-kneading balls of mud and putting these on the wall.

To make pisé, as well as mudbricks, a mixture of sediment that includes both sand and clay, water, and in most cases temper, such as chopped straw or chaff, is required. A wide range of sediments is suitable, or can be made suitable by adjustment. The sand and fine gravel components of the sediment form the aggregate of the mix (McHenry 1984: 48). These neither shrink nor expand and give strength to the mixture, although 


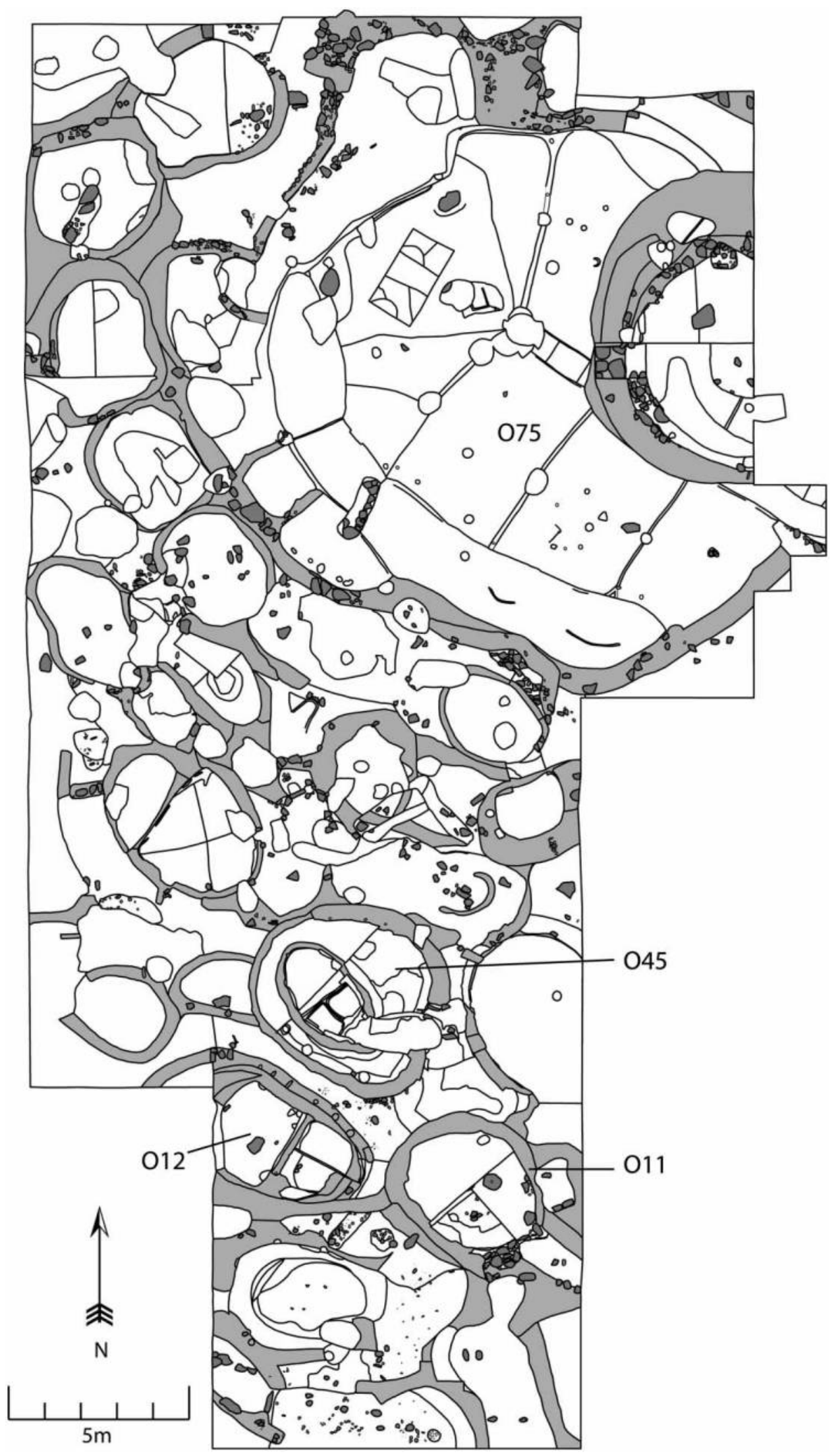

Figure 3 Site plan of WF16 showing dense clusters of semi-subterranean pisé built structures.

too much can make the material crumble (Rosen 1986: 75; Smith 2000: 133). Clay is plastic and sticky, and binds the mix (Keefe 2005: 37-39, 45-48; McHenry 1984: 48); nonetheless, too much clay will cause 


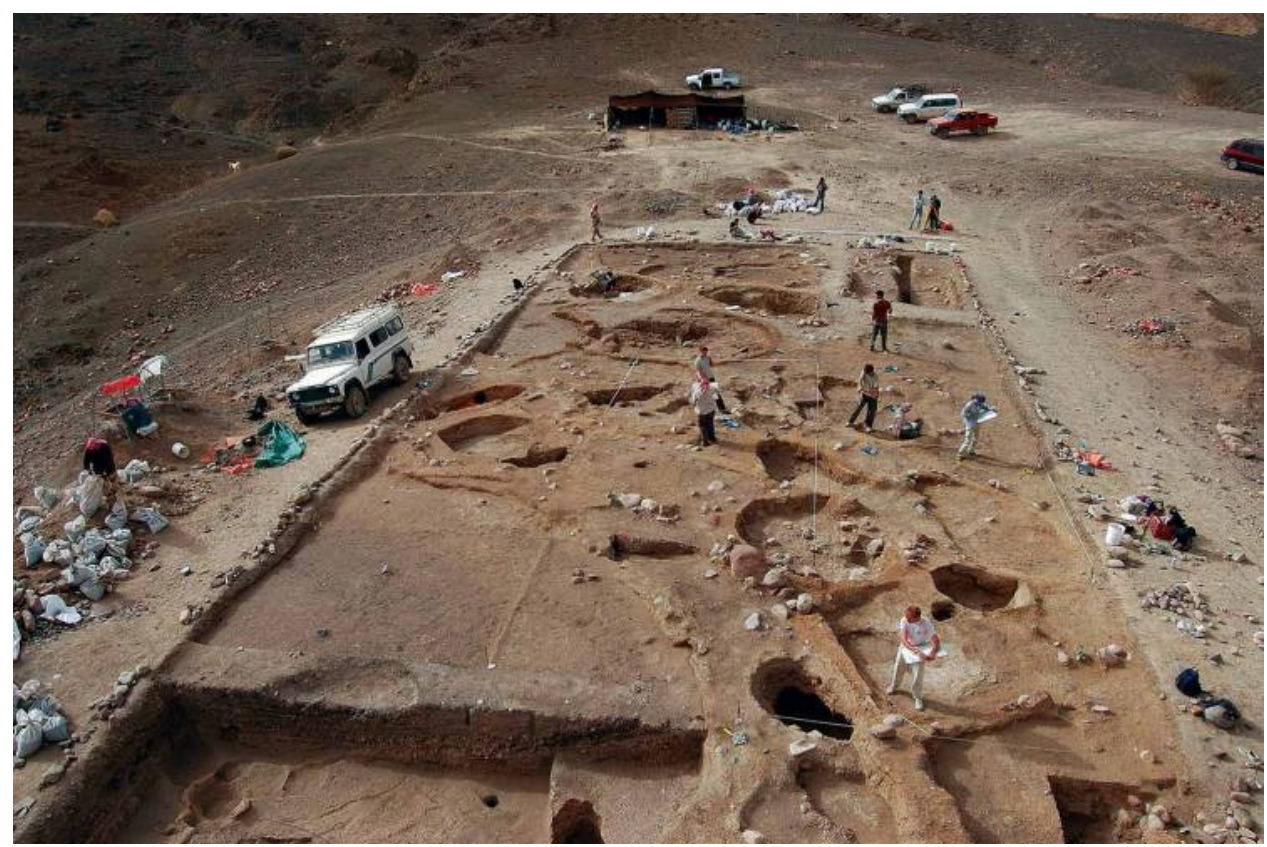

Figure 4 Excavation at WF16, April 2009, showing accumulation of midden deposits within structure 075 and a cluster of semisubterranean pisé built structures. Structure 011 can be seen in the far left part of the trench.

cracks, as it shrinks during drying. Clay-rich Egyptian sediments, for instance, were observed to shrink 30-37\% during drying (Fathy 1989: 89-90; Spencer 1979: 3). The proportions of sand to clay are therefore important. It is common practice to add botanical temper, such as straw, which also reduces cracking (Facey 1997: 84; Fathy 1989: 90; Keefe 2005: 57-58; Rosen 1986: 76). In addition, the plant temper helps to bind the mix, making it easier to keep the wall in shape, and increases the tensile strength of the material (Keefe 2005: 57). The use of plant temper has been attested archaeologically. The clearest examples come from sites in very arid regions, such as various Egyptian sites, where desiccated botanical remains are preserved in situ and where numerous plant inclusions have been found in building material, mainly of wheat and barley chaff (Cappers 2006; Flohr and Cappers 2008; Newton 2004; Smith 2003; Thanheiser 1999; van der Veen 2001).

\section{The archaeological evidence from WF16}

The experimental structure was based on the PPNA structures at WF16; it was specifically based on Structure O11 (Fig. 5), but non-conflicting information and features of other structures were incorporated as well, such as the presence of a niche in the walls as in Structure O12 (Fig. 5). Information regarding how the roof could have been made was based on well-preserved roof material from Structure O45 (Figs 5, 6) (see Finlayson et al. 2011b for a description of these structures and their context within the settlement).

\section{Architectural features and construction techniques}

Structures at WF16 were mostly small, semi-subterranean, circular to elliptical, with mud wall lining and mud-plaster floors (Figs 3-5; Finlayson et al. 2011b). Structure $\mathrm{O} 11$ is a typical example of this, measuring about $3.5 \mathrm{~m} \times 2.5 \mathrm{~m}$, with a cup-hole mortar placed within its floor (Fig. 5). The internal faces of the subterranean cut were lined with pisé, which was also used to construct the above ground walls, surviving to a height of $c$. $0.5 \mathrm{~m}$. Several mud-plaster floors were exposed during excavation. Indications of a stone-lined ramp leading to an entrance were also found. Although the walls of Structure O11 have not been sectioned, and future analyses of wall sections will be required to show precisely how they were built up, our preliminary interpretation was that the mud wall had been shaped while wet. In addition to this use of pisé, in some of the other structures at WF16 pre-moulded and possibly sun-dried lumps of building material had been used in the above ground walls, most clearly visible in the rapid backfilling of Structure O33. The excavation of walls elsewhere at WF16 exposed stone foundations; we suspect that these might also underlie the unexcavated walls of $\mathrm{O} 11$.

Evidence regarding how roofs could have been made comes from collapsed and burnt roof material found within Structure O45 (Figs 5, 6) (see Finlayson et al. 2011b). Charcoal interpreted as deriving from roof beams indicated the use of timbers, mostly of around $5 \mathrm{~cm}$, but up to $15-20 \mathrm{~cm}$, in diameter (although the charcoal was heavily burnt). Reed impressions indicate that the roof further consisted of reeds covered with mud. 


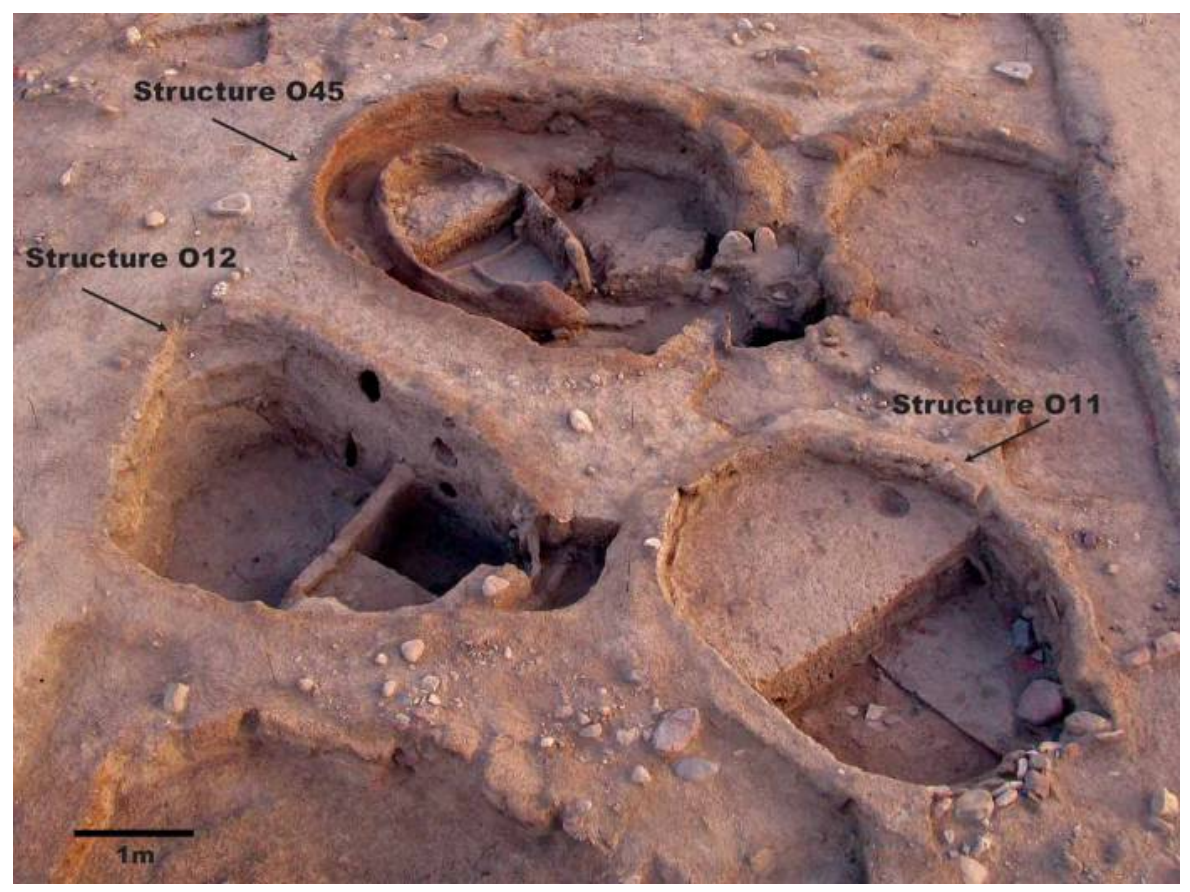

Figure 5 Structures 011,012 and 045 at WF16.

The roofs at WF16 were probably flat. There is no evidence for pitched roofs: there are no central postholes or indications of posts that could have supported such roofs (potential structural posts were only present in the large building O75). The existence of flat roofs is further supported by the fact that the beams found in O45 appear to form a frame, especially well visible in the east part of the structure (Fig. 6). In addition, chipped stone debris was found on surviving roof surfaces (and not within their fabric, indicating the chipped stone had not been incorporated in the roof mud by accident) (Finlayson et al. 2011b), showing that the roof was likely used as an activity surface.

Around Structure O45 a low ramp of loose earth was observed, apparently effectively raising the ground level around the structure above its semi-subterranean part. It is not clear if this was a structural feature, but the sediment appeared too loose to have been derived from roof or wall wash. In addition to future microstratigraphic analyses, the experimental work reported here (see below) is designed to help establish the function (or cause) of this ramp with more certainty.

\section{Materials}

The mud walls and floors of WF16 structures contained on average $9 \%$ clay, $51 \%$ silt and $40 \%$ sand (Elliott 2010). In addition, the walls contained plant temper. Voids from plant material were observed with the naked eye, and this was confirmed by micromorphological analyses. Wall pisé samples showed $10-30 \%$ voids formed by plant material that has since decayed (Elliott 2010; 2011). The floors on the other hand only contained a very small percentage of voids representing decayed plant material (Elliott 2011).

While it is so far unclear what plant species were used as temper at WF16, the use of cereal chaff and straw as temper in pisé in the Neolithic has been observed at other South-west Asian sites. Voids in pisé from the PPNA site of Dhra' showed straw and probable barley glumes (Finlayson et al. 2003a: 20-21; Kuijt and Finlayson 2009: 10967). Plant impressions were also abundant in pise of the PPNA site of Jerf el Ahmar in Syria and consisted of cereal chaff (of wild einkorn, wild barley and wild rye) (Willcox and Fornite 1999). In addition, charred rye and barley remains were found in pisé from Mureybet (Willcox and Fornite 1999). It is likely that the inhabitants of WF16 had access to grasses to use as temper, and possibly to cultivated wild barley. The latter has been observed in the vicinity of the site in spring, and the Early Holocene is in general believed to have been wetter than the current climate (Robinson et al. 2011), including in the Wadi Faynan area (Hunt et al. 2004; McLaren et al. 2004; Smith et al. 2011).

\section{The construct-rationale}

\section{Architectural features and construction techniques}

The experiment aimed to use similar materials and construction techniques as utilized at PPNAWF16, but did not attempt to use traditional tools and made use of modern transport. Modern tools were used, such as shovels to dig the pit and mix the mud mixture, 


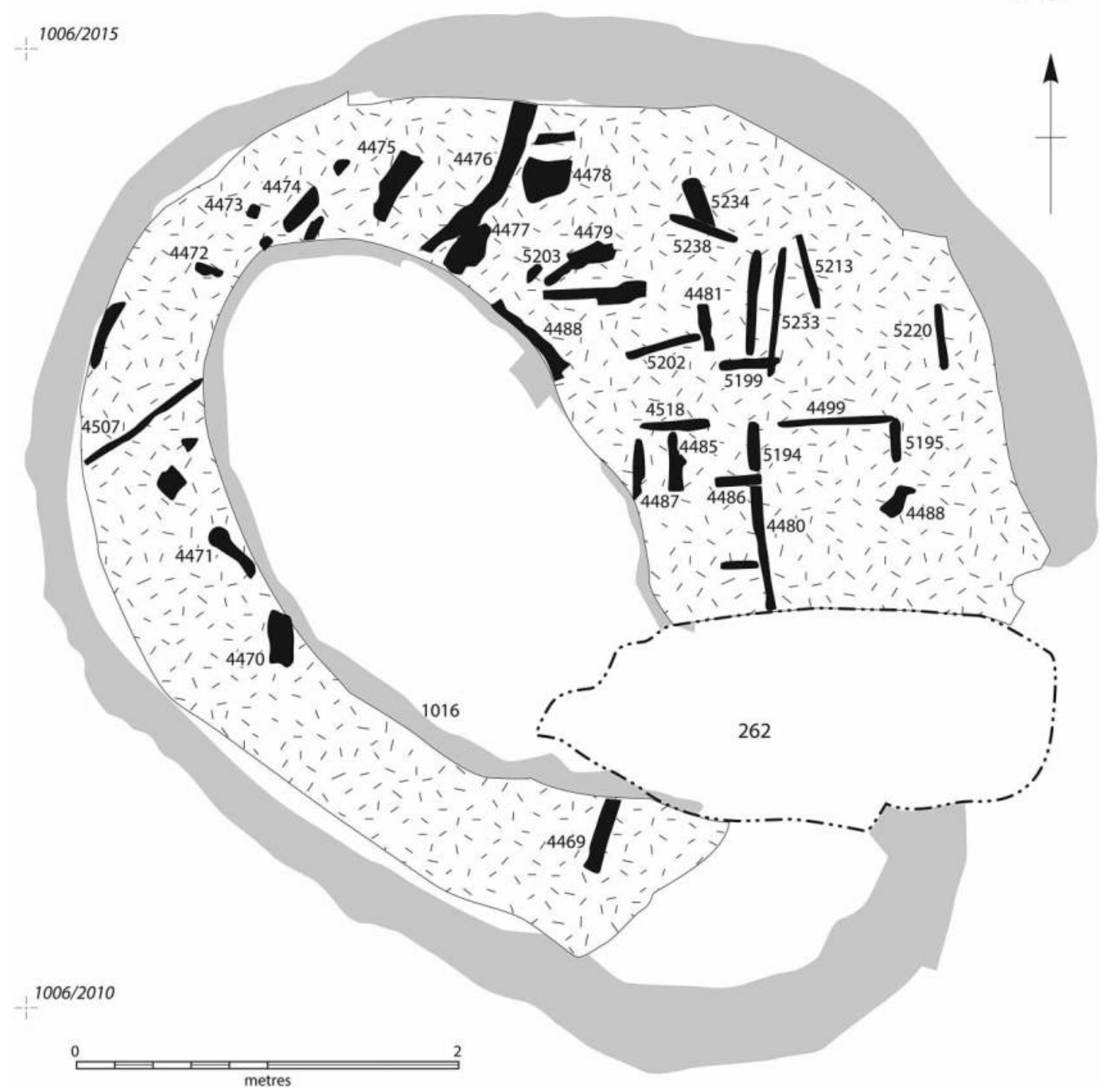

Figure 6 Plan of charred roof beams in Structure 045, WF16 (in solid black, mud walls in grey shading). The thinner beams in the east part of the structure have an N-S/E-W orientation, while the thicker beams in the western part are on a NW-SE/ NE-SW orientation.

pickaxes to mine to soil, and plastic containers to move materials. While these are not realistic replacements for PPNA tools, which would presumably have consisted of stone and wooden implements and baskets or skins, this experiment was focused mainly on the architecture and not the working methods.

The knoll to the immediate west of that on which WF16 is situated was chosen as the location for the construct (Figs 1, 2). Previous fieldwork (Finlayson and Mithen 2007; Mithen et al. 2007a) had shown there are no archaeological remains on this knoll.

As explained above, the experimental structure was based on Structure O11 from WF16 (Fig. 5), but nonconflicting information and features of other structures were incorporated as well, especially roof evidence from Structure O45.
As the evidence at WF16 points at the use of pisé for the majority of the walls (see above), this material was used to line the pit walls of the construct. Because premoulded lumps were also observed at WF16, and as loaf-shaped mudbricks have been observed at other PPNA sites in the southern Levant, such as at Gilgal, Netiv Hagdud and Jericho (Bar-Yosef 1995: 192), it was decided to use these in the building process as well. This had the additional advantage of allowing for a comparison of these different techniques.

Based on the evidence from Structure O45 (Fig. 6), it was decided to build a roof of wooden beams and reeds, covered with mud. PPNB structures at Ba'ja and Shkârat Msaied show evidence of flat roofs made of similar materials (Gebel and Hermansen 
2004: 17; Kinzel 2004: 19; Purschwitz and Kinzel 2007). Moreover, until recently, when mudbrick houses were built in Jordan they generally had flat roofs supported by wooden beams (Dennis 2008; Haberkorn 2000; Kinzel 2004; see also Seeden 1985), although dome roofs made of mudbricks have also been observed in the wider region (observation Pascal Flohr, Syria, 2003). The evidence for flat roofs at WF16 appears fairly strong and there is no archaeological evidence at the site for pitched roofs. Moreover, when experimental roofs with a steep angle were built at Beidha, the mud was washed away by rain (Dennis 2008), while flat roofs were damaged by puddles of standing water (observation Bill Finlayson). The archaeological evidence at Beidha does, however, indicate that slightly pitched roofs were utilized (Dennis 2003a: 43), and experimental pitched roofs with a relatively shallow angle survived several years of winter rains (Dennis 2008; observation Bill Finlayson). This impression had been confirmed in discussions with traditional builders in northern Cyprus, who argued that very slightly domed surfaces sufficed to shed water at a sufficiently low energy to avoid the erosion problems of a pitched roof. The mud of the WF16 construct was shaped in a slight dome; in this way it will be possible to explore whether this is indeed sufficient to let the rainwater run off.

In the construct the walls support the roof. As no structural postholes were present in most of the WF16 structures this is consistent with the archaeological record. It has been argued that PPNA roofs would have been supported by posts instead of the walls (e.g. Banning 2003). This experiment aimed to test whether walls of around $20 \mathrm{~cm}$ wide, as observed at WF16, are able to support a wood and mud roof.

To test whether the low earthen ramp around Structure $\mathrm{O} 45$ at WF16 was structural or taphonomic, a ramp was placed around the construct too. A comparison between the loose earth of this ramp and the likely more solid wall and roof wash that is expected to form on top will allow us to better distinguish between these in the archaeological record.

\section{Building materials}

Based on the analysis of archaeological samples of building material from WF16 (Elliott 2010; 2011; see above) and ethnographic examples, it was decided to use a mixture of sediment, water and plant temper. Materials for the construct were sought close to the building site. In ethnographic sources, the material used for earthen buildings was generally derived from a nearby location (Damluji 1992; references in
Friesem et al. 2011; Horne 1994; Watson 1979). Because the key materials are heavy to transport, and because a wide range of sediments can be made suitable for pisé (see above), it is assumed that at WF16 the building materials were locally derived.

The only commodities that could not be locally found at the time of construction were cereal straw and chaff. Nonetheless, the decision was made to use barley and wheat straw, because of the archaeological evidence indicating its use at other Neolithic sites (see above). Moreover, wild grasses have been observed on and close to the site of WF16 in spring, including a variety of wild barley. The absence of grasses close to the site at the time of the experimental construction in early autumn can simply be explained by the fact that their growing season in the region is from late autumn to spring.

\section{Availability of materials}

\section{Stones}

Stones of various sizes were available on the knoll where the construct was to be located and from the wadi bed of the nearby Wadi Ghuwayr. As the knoll of WF16 is, like the knoll of the construct, a gravel river terrace, inhabitants of WF16 would have encountered such stones when digging pits for their structures.

\section{Sediment}

The aim was to find a sediment source close to the site that would be as similar to WF16 architectural sediment as possible. The analyses of the sediment composition of ridges south of WF16 showed that these were broadly comparable in clay, silt and sand content, but had relatively high gravel contents (Elliott 2010). The sediment at the building site itself proved to be unsuitable for the same reason. Sediment from the floor of the nearby Wadi Ghuwayr was also comparable to the WF16 samples (Elliott 2010), but was too limited in availability for the quantity required for the construct.

To find another suitable sediment source, samples of sediments in the immediate surroundings of WF16 and the building site were taken. These were tested for their stickiness (i.e. whether or not they contained enough clay), sand content, and compactness and friability when made into mudbricks. Sediment from one of the wadi terraces of the Wadi Ghuwayr (Figs 2,7) proved to be most suitable. It was mined using pickaxes and transported to the experimental site in a pickup truck.

\section{Water}

Water is currently present all-year round in the Wadi Ghuwayr (Fig. 7). During the construction, which took place in October, no water was present in the 


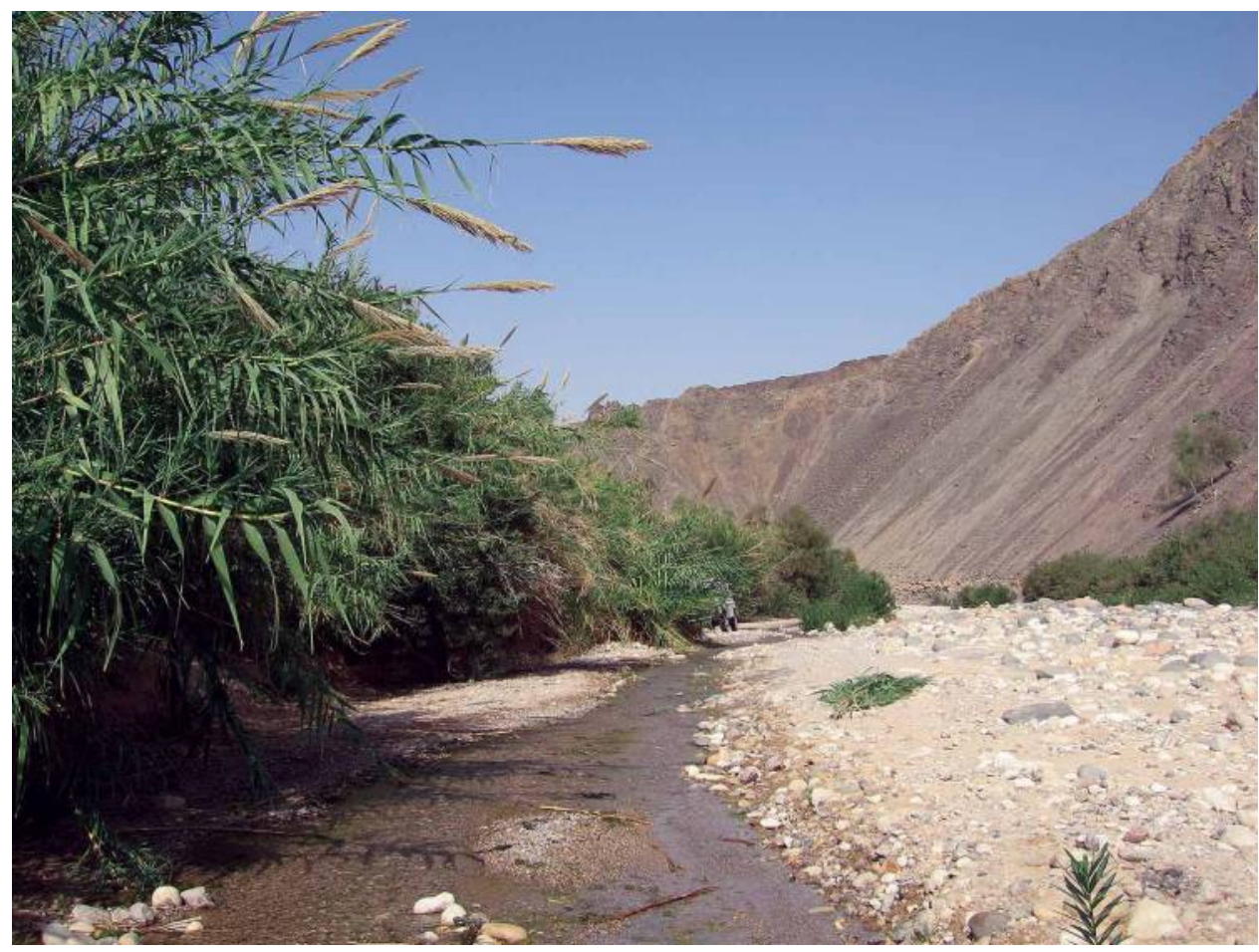

Figure 7 Wadi Ghuwayr with water and reeds, several hundred metres from WF16.

wadi where it ran past the site, but it was available just a few hundred metres upstream. For practical reasons most of the water actually used in the construct was taken from a tap in a house in the nearby village, with the wadi water only being used for additional water required during the day. Water was transported to the site in large plastic containers in a pickup truck.

\section{Botanical temper}

Barley straw and chaff (with a little wheat straw and chaff) were used as organic temper in the construct. Bags of chopped straw and chaff were purchased in a nearby village, where they are sold as animal fodder. As discussed above, grasses are available near the site in spring, while other plant species were growing in the vicinity of the site at the time of the experimental work.

\section{Wood and reeds}

The wooden beams for the roof were also derived locally. Because of the present day scarcity of wood due to the climate and intensive grazing, official permission is required in Jordan to fell any trees (Dennis 2003a: 44-45), so wood was bought, from a local farmer. Tamarisk (Tamarix sp.) wood was used, available in timbers around $8 \mathrm{~cm}$ and $12-14 \mathrm{~cm}$ in diameter. Tamarisk is local to Wadi Faynan and represented in wood charcoal from WF16 (although the charcoal of the found roof beams has not yet been identified to species).
Reeds, also used in the roof, can be found close to the site, a few hundred metres upstream along the Wadi Ghuwayr (Figs 2, 7). Because permission is also required to cut reeds, previously cut reeds and purchased reed mats were used.

\section{Preparing the materials}

Sediment, water and plant temper were mixed together in a ratio of two parts sediment with one part water and one part temper. Some initial experimentation was undertaken to decide upon the quantity of temper that appeared to minimize cracking of the pisé during drying. The quantity of water was determined pragmatically to produce a relatively thick mix that could be applied almost immediately. The mixing was done next to the construct and was undertaken by using shovels, as well as by trampling. The mixing of mud was generally done in batches of about 200 litres of sediment, 100 litres of water and 100 litres of plant temper at a time, and was a process that needed to be repeated numerous times throughout the construction (Tables 1, 2).

The experimental mudbricks were made using the same mix. They were shaped by hand and dried in the sun. Because of the handwork the size and shapes of the mudbricks used in this project varied, but generally they measured around $28 \mathrm{~cm} \times 17 \mathrm{~cm} \times$ $6 \mathrm{~cm}$. For mortar and mud-plaster the same mixture 
Table 1 Approximate hours of labour per activity

\begin{tabular}{ll}
\hline Activity & $\begin{array}{l}\text { Approximate total } \\
\text { hours }\end{array}$ \\
\hline Digging of pit & 73 \\
Gathering raw materials & 100 \\
Mixing mud (might be under & 135 \\
$\quad$ represented) & 117 \\
Applying layers/mudbricks/plaster & 47 \\
Making mudbricks & 13 \\
Shaping the roof & 37 \\
Other (incl. tests with mudbricks, looking & \\
$\quad$ for suitable soils) & 40.5 \\
Unaccounted for (incl. documentation) & 562.5 \\
Total & \\
\hline
\end{tabular}

was used again, only made wetter so that it could be easily shaped.

The mix for the floor was made in the same way as the general mix, but without adding plant temper, as floors at WF16 generally contained only a very small percentage of voids representing decayed plant material (Elliott 2011; see above).

\section{Construction}

Construction took place in the following phases:

(1) an oval pit of $2.5 \mathrm{~m} \times 3.5 \mathrm{~m}$ and $1.2 \mathrm{~m}$ deep was dug (Fig. 8). This took around 73 person hours in total, or 2 days with six to eight people (Table 1).

(2) a cup-hole mortar was placed in the middle of the pit. It was necessary to do this at this stage, in order to avoid damaging the walls later on.
Table 2 Amounts of mud mixture used in the construct. Amounts were measured using 20 litres plastic buckets. As the mud mixture was heavy and the buckets would break when filled to the edge, each bucket contained around $\mathbf{1 7 . 5}$ litres instead

\begin{tabular}{lll}
\hline Feature & Buckets of mud & Litres $^{*}$ \\
\hline Walls & 150.5 & 2634 \\
Mudbricks & 42 & 735 \\
Plaster and mortar & 37 & 648 \\
Ramp & 4 & 70 \\
Floor & 21 & 368 \\
Roof & 68 & 1190 \\
Total & 322.5 & 5644 \\
\hline
\end{tabular}

*Assuming one bucket contains 17.5 litres of mud mixture.

(3) a foundation layer of boulders (each up to $0.2 \mathrm{~m}$ in length) was laid around the edge of the base of the cut (Fig. 9).

(4) the stone foundation was covered with a first layer of the mud mix. When this layer was leather-hard, i.e. dry enough not to collapse when additional weight was applied, but not so dry that the next layer would not stick to it, a second layer was applied. This sequence was repeated until the top of the pit was reached, every time applying a layer of $10-15 \mathrm{~cm}$ (Fig. 10). Each layer, containing around 140-150 litres of mud, took three people around one hour to apply. Although individual members of the team developed their own preferences, in general the mud was applied by either kneading it in the hand and subsequently pressing it onto the wall, or by putting some mud on the wall and pressing hard into it. A niche was made within the wall

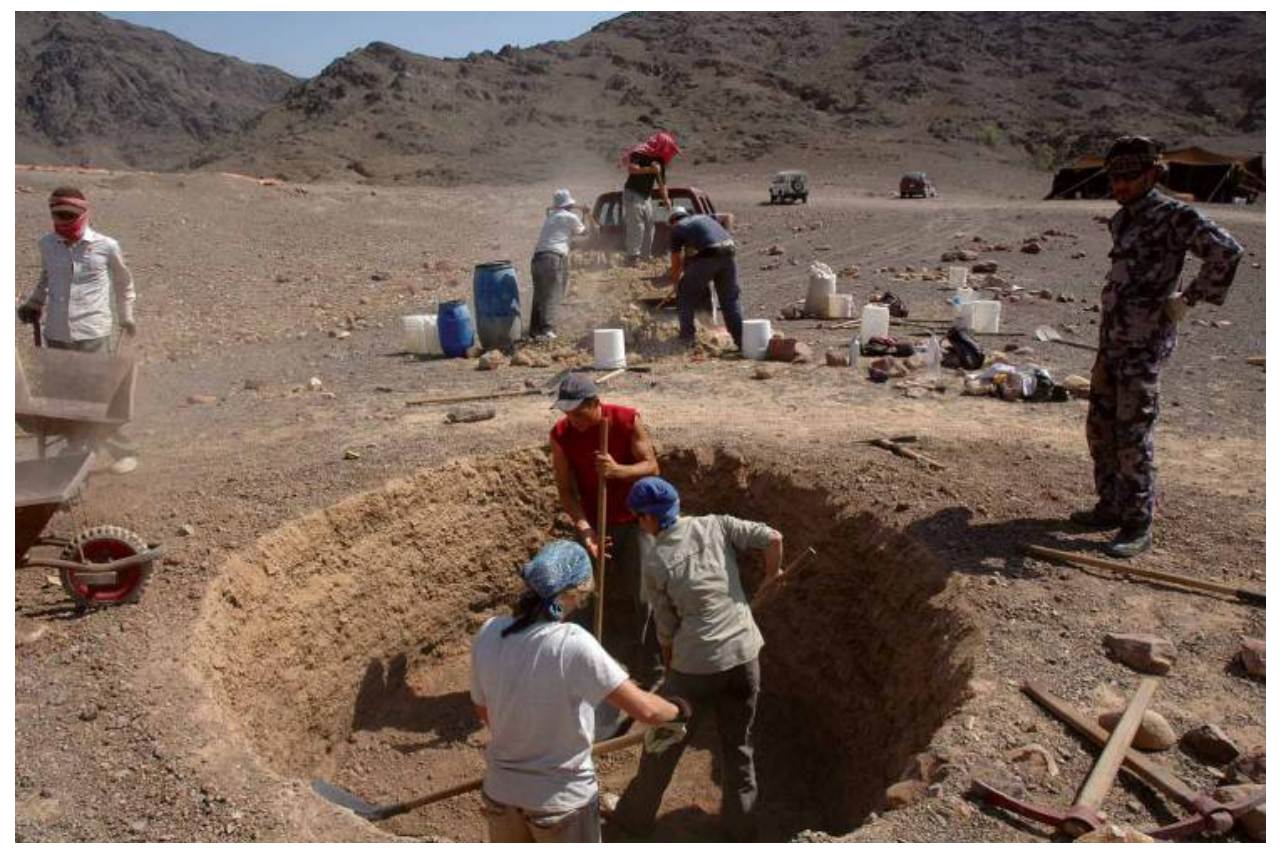

Figure 8 Digging of the pit, which measured $2.5 \mathrm{~m} \times 3.5 \mathrm{~m}$ on top and was dug $1.2 \mathrm{~m}$ deep. In the background a load of sediment is unloaded. To the left, part of WF16 is visible. 


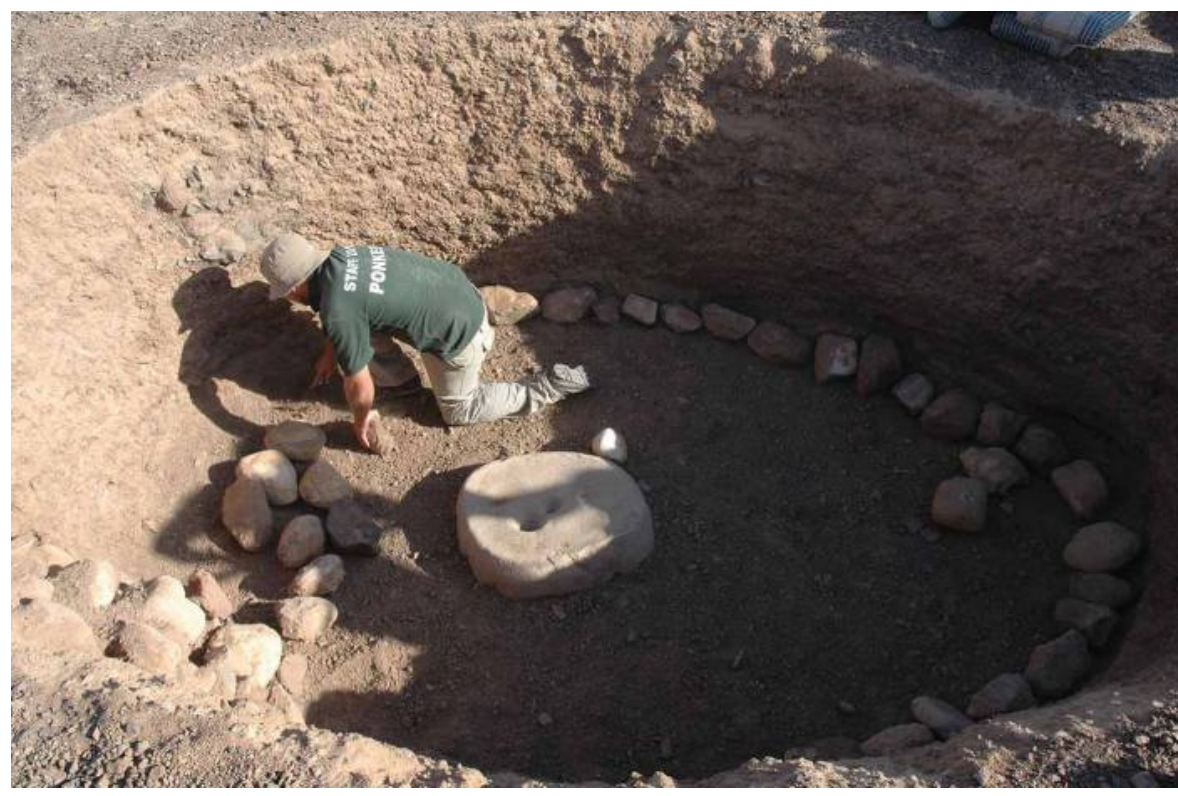

Figure 9 Laying of the foundation layer of boulders.

with flat stones. When parts of the wall began to become too thick where they bulged inwards because of the weight of wet mud and because the edges of the pit cut sloped slightly outwards, the wall was realigned by stepping the next layer in. In the northern part this was done once, in the southern part twice (Fig. 11).

(5) a ramp was made on the south-eastern side of the building, to lead to the entrance; it was constructed by setting boulders in mud (Fig. 12). The digging of the ramp took two to three people less than an hour, the construction took one person about 2 hours.

(6) at the same time (contemporaneous with steps 4 and 5), 210 mudbricks were formed and sun dried. Once the wall below the ground surface was complete (Fig. 12) these bricks were laid lengthwise (with the long side in line with the building, i.e. the short side perpendicular to the building) in six to seven courses each one brick thick, bound together by mortar, to form a $c .40 \mathrm{~cm}$ high wall on top of the mud wall (Fig. 13). The walls were immediately plastered. While it would have been more beneficial to have done this after the walls had dried, to prevent cracking of the plaster as the walls dry, time precluded this. Cracks in the plaster were filled up during the next days. Whereas the preparation of the mudbricks had taken up a considerable amount of time (Table 1), the laying of the wall was very quick and took less than 2 days.

After this stage, the walls were finished at a height of $1.60 \mathrm{~m}$, were $c .20 \mathrm{~cm}$ thick (18 cm on top) and contained around $4 \mathrm{~m}^{3}$ of mud mixture (Fig. 14). The making of the walls, including the gathering of the various materials and the mixing of the mud had taken $c .377$ person hours, or 11 days with a team of four to nine people (seven people on most days), including one rest day to allow the walls to dry out (Table 1).

(7) a low 'ramp' of loose earth was laid around the outside of the walls. The gravel rich sediment dug up from the pit was used for this.

(8) an approximately $5 \mathrm{~cm}$ thick mud-plaster floor was laid inside the walls, around the cup-hole mortar. This took two people (plus people to hand them buckets) less than an hour.

(9) after the walls had dried for 3 days, the roof was built. Tamarix beams were placed parallel to one another spanning the walls. Four bigger beams of $12-14 \mathrm{~cm}$ in diameter and three thinner beams ( $c$. $8 \mathrm{~cm}$ ) were used. Thin beams, long branches and reeds were placed over these, perpendicular to them (Fig. 15). This covered three-quarters of the building, excluding the entrance area at the ramp (to allow visitors to look into and enter the building easily). Mud mix was then applied to weigh the beams and reeds down and, most importantly, to make the roof waterproof (Fig. 16). As mentioned before, the mud was applied to form a very slight dome shape to allow rainwater to run off the roof and not form puddles. The roof was built in slightly more than 2 days with three people, excluding the gathering of materials for the mud mix on top.

\section{Observations and problems}

\section{Materials}

In total around 6000 litres of dry sediment, over 2700 litres of straw and almost 3000 litres of water were used to make around $5.5 \mathrm{~m}^{3}$ of mud. The large 


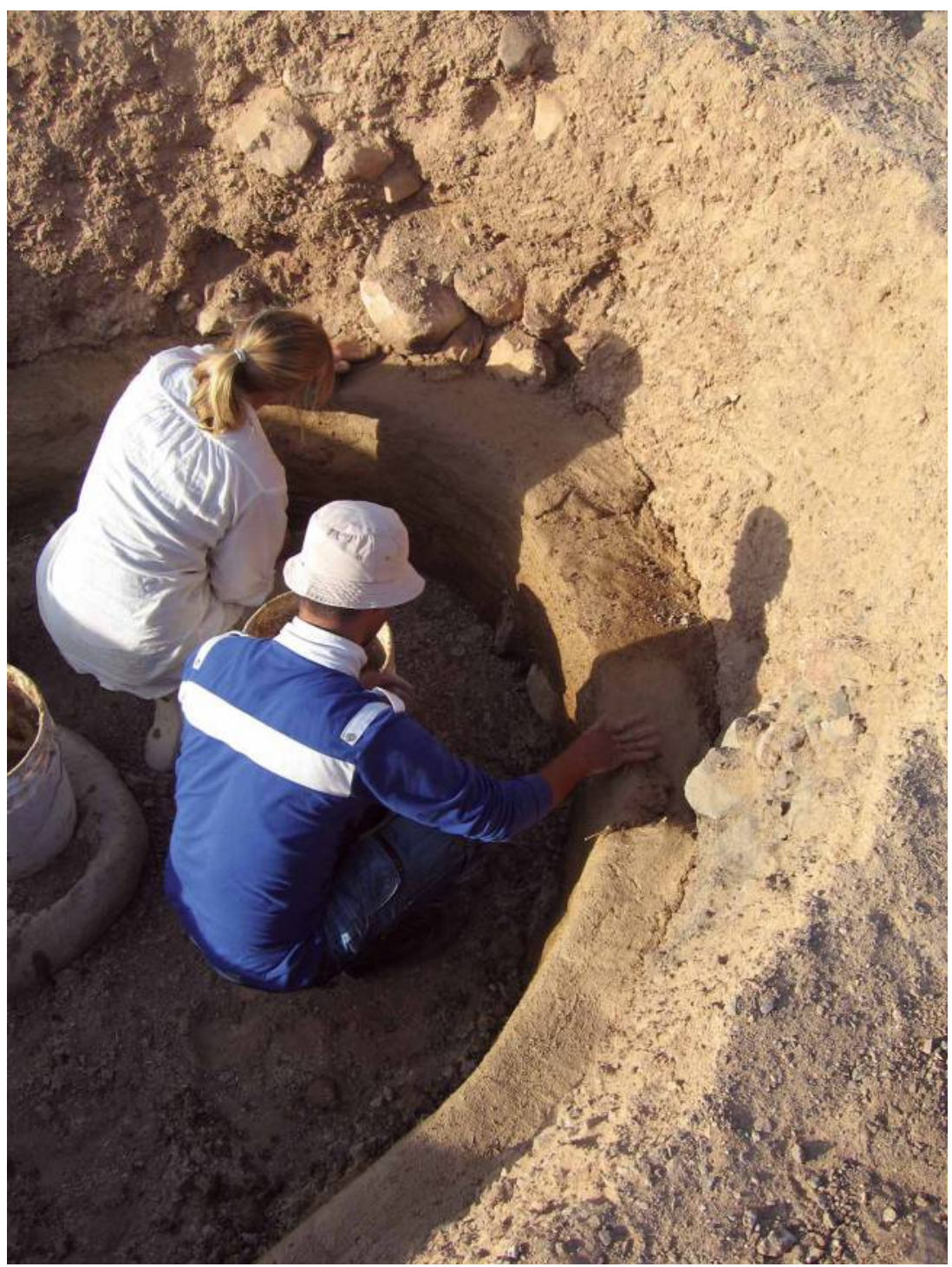

Figure 10 Application of wet pisé layers of $10-15 \mathrm{~cm}$ thick each.

majority of this (around $4 \mathrm{~m}^{3}$ ) was used for the walls (Table 2). The ratio which appeared to give the best results was using twice as much volume of sediment as water and plant temper. No sand or gravel was added, as this appeared not to be necessary. In the literature different ratios can be found (e.g. Facey 1997: 114; Fathy 1989; Horne 1994: 162-63; King 1998: 13; Moquin 2000: 104), which is logical, as different types of sediment need different amounts of temper (see above). Facey (1997: 114) noted a use of as much as one, or even one-and-half times, as much water as earth. Adding more water would make the mixing easier, and if the mixture was left to ferment this should make the mix crack less and become stronger and less absorbent as bonding minerals would be released (Facey 1997: 84; Fathy 1989: 90; Rosen 1986: 76; Thomas 2005: 17). However, time restraints meant that this was not possible in this case, and it is not known if the WF16 inhabitants would have left their mixes to ferment or not. In any case, the resulting mud wall was strong and showed only a few small cracks.

\section{Availability of materials}

Sediment, water, wood and reeds were all locally available, whereas wild grasses can be found in the direct vicinity of the site in spring. Nonetheless, water, wood and reeds are nowadays scarce in Jordan, and permission to cut trees and reeds is required at all times (see also Dennis 2003a: 44).

While even today a perennial source of water is present near WF16, and the Early Holocene probably had a wetter climate in the southern Levant (e.g. BarMatthews et al. 2003; 1997; 1999; Goodfriend 1991; 1999; Hunt et al. 2004; McLaren et al. 2004; Robinson et al. 2011), the almost 3000 litres used for the construct would be hard to find today in other 


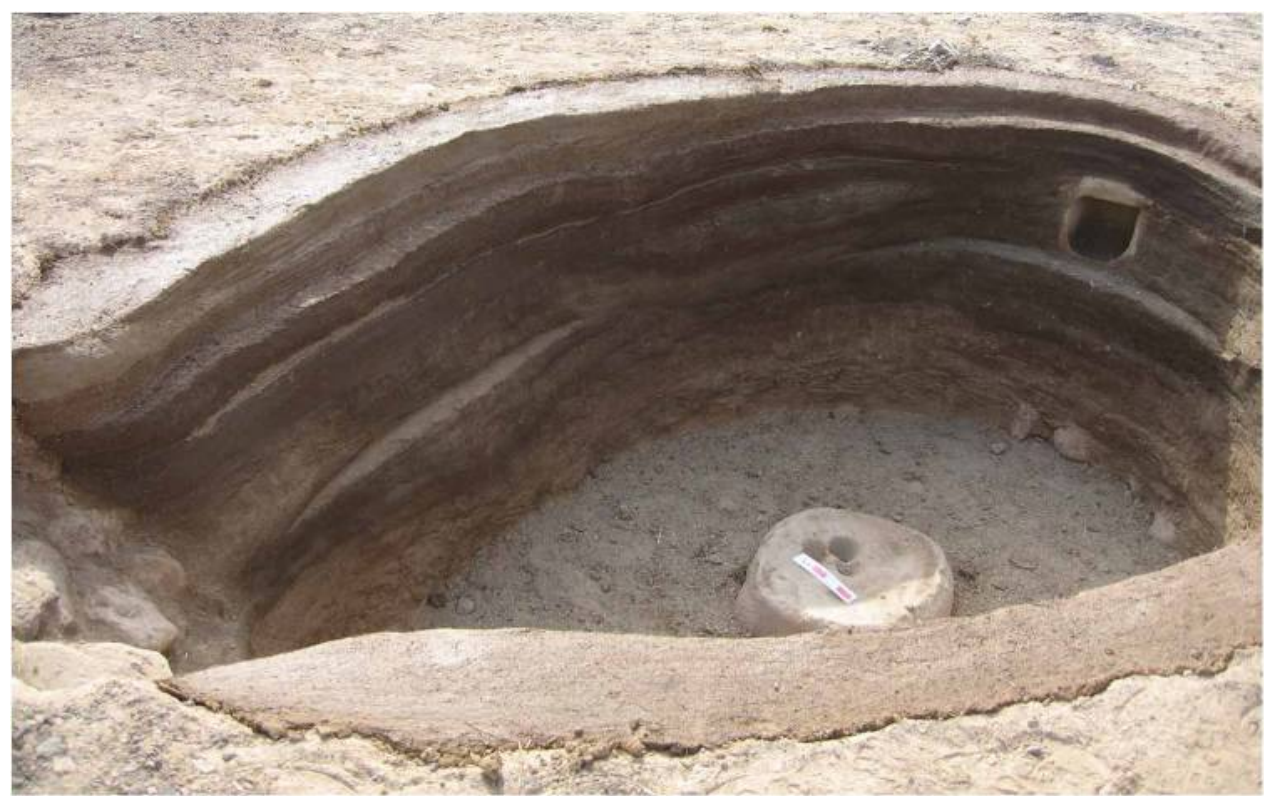

Figure 11 Stepping in of the southern wall, to avoid the wall becoming too thick as a result of bulging of wet walls and sloping edges of the pit.

areas, such as around Beidha (Dennis 2003a: 44). Moreover, the building of a large structure, as Structure O75, in the middle of summer is likely to have put a strain on the resources (while in other seasons rainfall, increased humidity and/or lower temperatures would have made the drying process slow).

As the Early Holocene was probably wetter than today, and especially because overgrazing and the use of wood for fires for copper smelting had not yet commenced, the supply of wood was probably much less of a problem then than it is now. Some wooded areas are still present higher up in the mountains and it has been argued that access to juniper woodland, evergreen oak woodland, as well as riparian woodland would have been available to WF16 inhabitants (Mithen et al. 2007b).

Unexpectedly, it proved difficult to find a sufficient amount of suitable sediment, i.e. sediment that contained some, but not too much clay, and some, but not too much sand. Nonetheless, the inhabitants of WF16 would presumably have been very familiar with the area, would therefore have known where to find good sediments, and they would not have been limited to sources accessible by car. Furthermore, even though this is more time consuming, by adjusting the sediment, i.e. mixing different types, removing gravel, or adding clay/sand, a wide range of sediment deposits can be made suitable.

\section{Construction}

Several conclusions can be drawn concerning the construction of pisé structures in general and at WF16 in particular. Overall, the method used here, as adapted from ethnographic sources, the archaeological evidence, as well as our practical experimentation, works well and it is probable that PPNA mud walls were built in at least a similar way, using similar materials. Future work sectioning both the experimental walls and WF16 archaeological walls will indicate whether or not the techniques used are indeed the same.

The application of wet mud on the walls had certain disadvantages. Because it was necessary to wait for every layer to dry before applying a new layer, the construction required waiting time. In this time other activities could be conducted: material could be mixed and new raw material could be gathered. However, this does mean that however many people are available to build a structure, there is always the limiting factor of having to wait for the walls to dry. This suggests that even building a relatively small mud structure like this one requires a stay at, or frequent returning to, a site for at least several weeks.

Because of the limited time available for this project and the time of year, new layers were applied when the previous wall layers were still fairly wet. A specific problem occurred, especially at the base of the pit in the southern part, as it was almost constantly in shade, significantly slowing drying in this part of the structure. As a result, even though thinner layers were applied here, the wall started to bulge under the weight of material being added. In addition, because the sides of the pit were not absolutely vertical, the wall thickness increased with height, increasing the volume of material to dry. Because of these two 


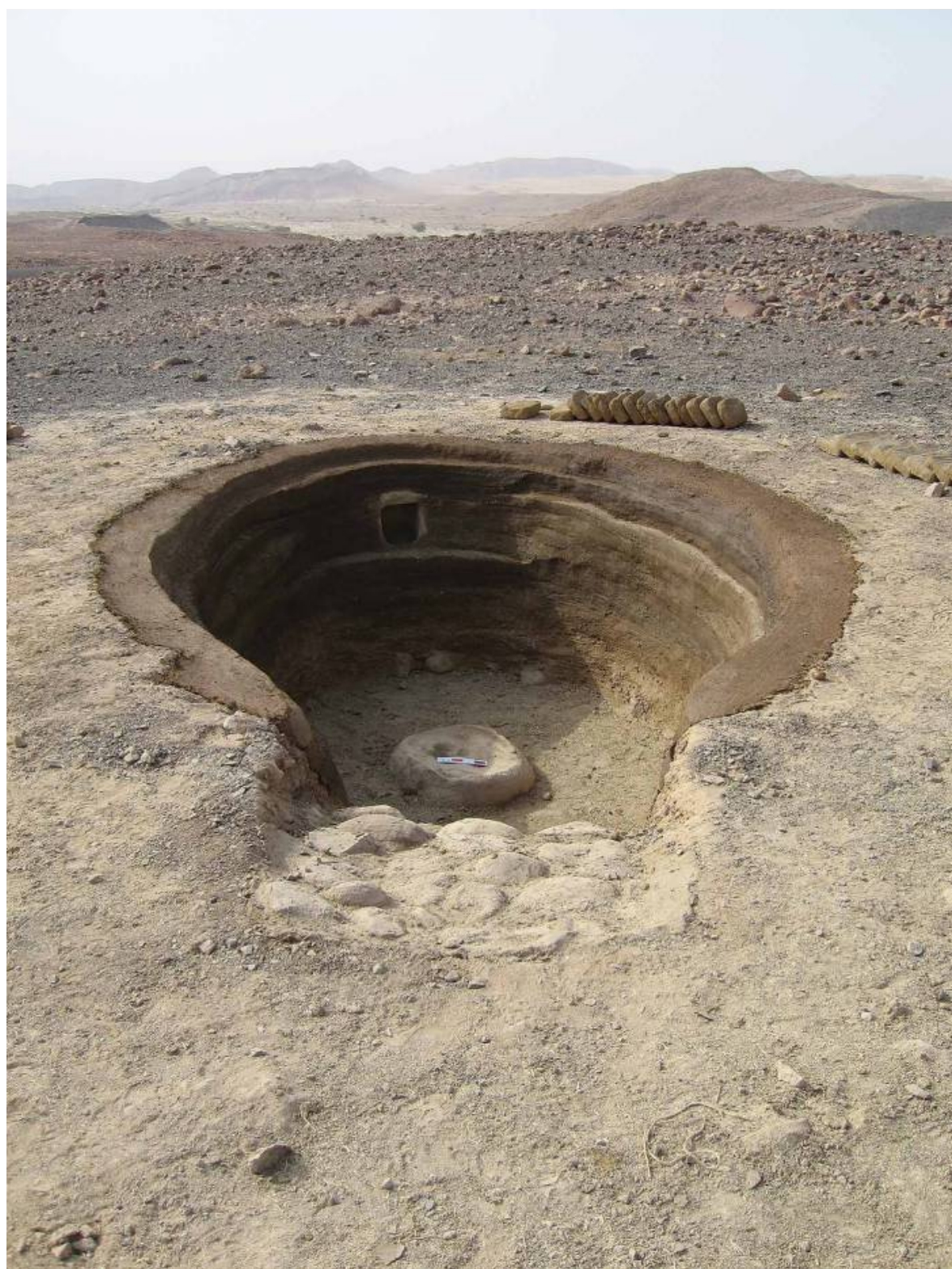

Figure 12 The finished pisé wall (looking north-west), with the ramp on the foreground, and the niche in the west part of the wall. The different layers are drying in different colours. The stepping in of the wall is visible.

factors, it was decided to step the wall in. This was done twice in the southern, shaded part (Fig. 11), and once in the northern part. Interestingly, stepped walls had also been found in Structure O11 at WF16. These had been interpreted during excavation as indicating a realignment of the wall; the current study's experimental work suggests a simple pragmatic structural technique may have been responsible for this archaeological feature.

In general, the walls of the replica structure sloped out. The pit had slightly sloping sides to start with, which became more pronounced as construction materials were moved in and out of the pit during the building, eroding the gravel pit faces. Although the walls were built with a more vertical inner face, they echoed the general slope. The off-vertical face was exacerbated by the presence of the bulges mentioned above.

As the mudbricks were dried before use in the construction, there were no problems with wetness, bulging and sloping of the mudbrick part of the wall. Although the mudbricks required some time to prepare, the wall could be built quickly. It is therefore not hard to see why the use of mudbrick was later (after the PPNA) more widely adopted instead of the use of pisé.

The floor surface cracked severely during drying. This was probably caused by the absence of plant temper in the mix in combination with the thickness 


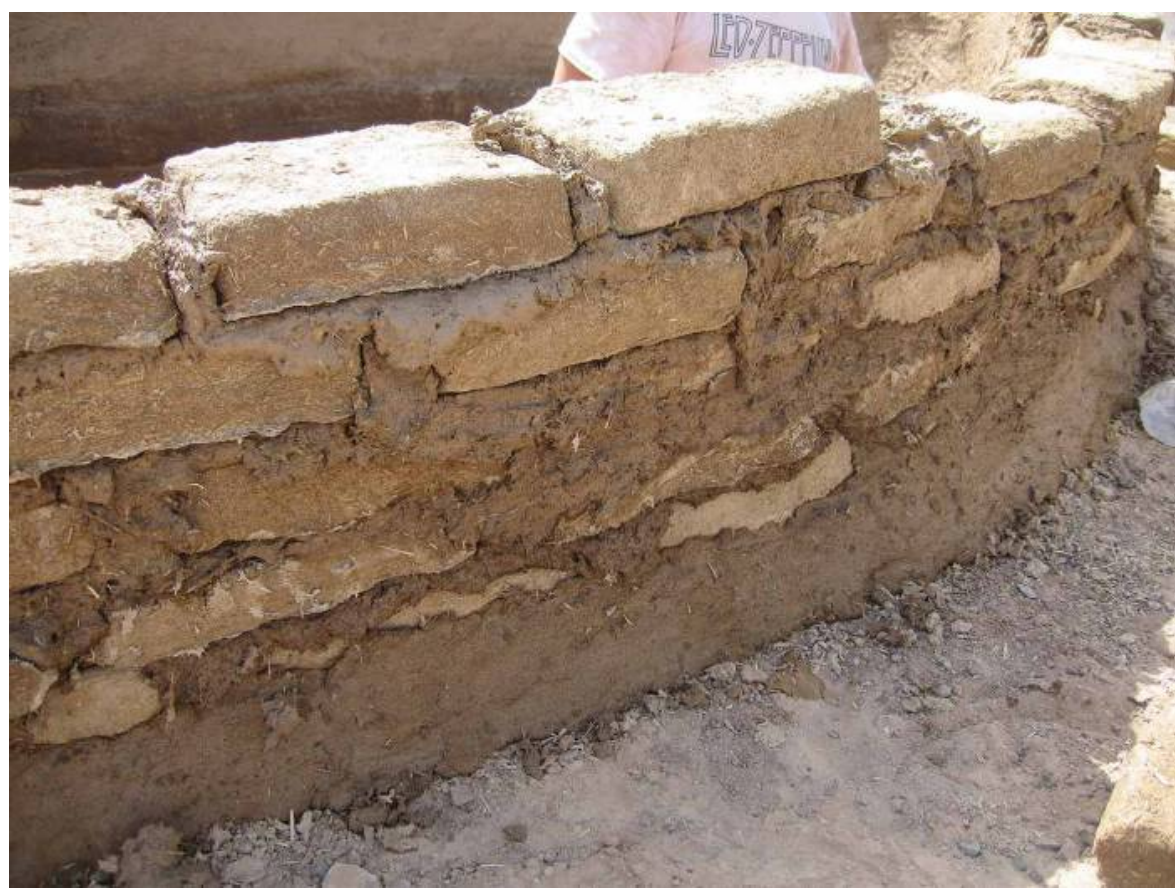

Figure 13 Mudbrick wall, bound with mortar and in the process of being covered with mud plaster.

of the layer $(c .5 \mathrm{~cm})$. At WF16 no plant temper was observed in floor layers either, but the layers of plaster put down at any one time appear to have been much thinner. It was necessary to construct the replica floor as one thick layer, as time was running out, and this was our main deliberate divergence from the archaeological data. Most floors at WF16 have a thick foundation and a thin plaster, sometimes with several layers, which appear to be more stable and less prone to cracking. In addition, while analysis has shown that WF16 floors and walls were similar in texture (Elliott 2010), it is possible that the sediment used in the construct has in general more clay than that used at WF16 (this is being tested by ongoing analyses). This was not a problem for the walls, as they contain plant temper, like the walls at WF16, which diminished any cracking.

The construction of the roof appears to work well. The beams were laid on top of the walls, where their weight and the weight of the mud on top kept them in place. It is possible that in the WF16 buildings the beams would actually have been set in the upper

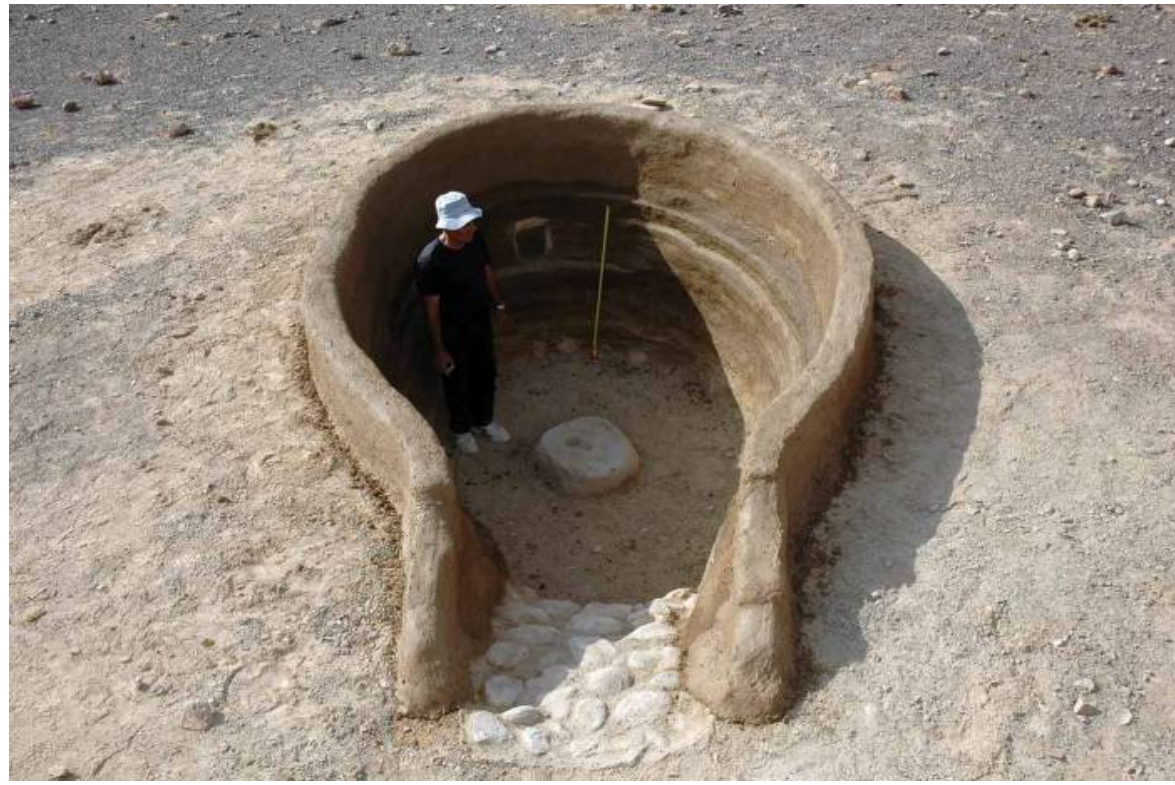

Figure 14 Finished wall with human scale and measurement tape (1 m scale). 


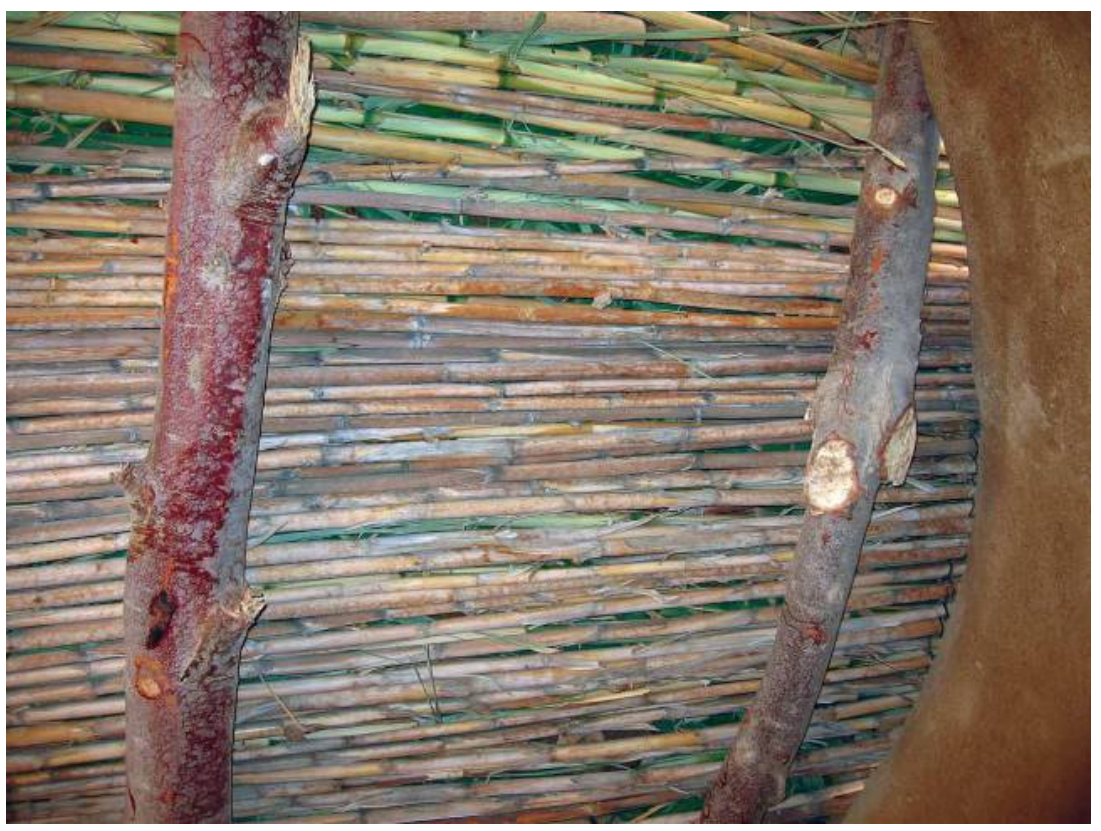

Figure 15 Roof construction with wooden beams supporting reeds (in turn supporting mud), seen from below.

layers of the wall, as observed in modern mudbrick construction (e.g. Keefe 2005). Also, in this case the only beams available were bent. While this might have been the case in some PPNA structures as well, this resulted in having to use more mud on top than would have been the case with straight beams, to avoid a concave roof, in which puddles of water might collect and damage the roof. Even though the walls were only about $20 \mathrm{~cm}$ wide, they were strong enough to carry the weight of the roof. As other structures at WF16 had walls of either similar or a greater width, and in the absence of postholes, this confirms that the roofs could have been directly supported by the walls. Moreover, the roof and its supporting walls proved strong enough to allow herds of goats and people to walk over it, indicating that it was possible to use such a roof as an activity area (see further below).

The roof covers most of the building, but does not cover the ramp entrance and the part adjacent to it, as the entrance way would otherwise have been very low and small. This would probably have been more authentic and weather proof, but would weaken the public presentation aspect of the structure. It is possible that entrances of structures at WF16 were somewhat larger if the walls stood higher than the $1.6 \mathrm{~m}$ used here, but a small entrance has also the advantage of keeping heat and cold out of the building.

\section{Work load}

Inferences about labour input based on modern experiments can only be approximate, and the more so if fewer aspects of the experiment are authentic. Moreover, skill and experience of participants in the experiment will differ from those of people in the past. In this case, it was not the aim of the experiment to reconstruct the exact time needed to build a Neolithic structure, and we did therefore not attempt to use authentic tools. Therefore, any observations represent minimum hours only, which should be multiplied by an unknown amount to get the time that was needed in pre-modern times. On the other hand, the experience and expertise that people used to building with mud have over that of our team would diminish this gap. Keeping this caveat in mind, we believe that our observations on work load provide some useful basic parameters.

Including the gathering of the materials, more than 560 hours, in total, were spent building the construct over a 3-week period with a team of 3-10 people per day (averaging around 6) (Table 1, see also above). These 3 weeks include time to wait for the walls to dry, although as explained above, this waiting time should ideally have been increased. Because the time needed for the walls to dry is an important factor, the time needed to build a structure will vary with weather and is thus seasonally variable.

As mentioned above, the 562 hours observed here significantly under-represent the time it would have taken to build a structure like this in pre-modern times. For instance, the digging of the pit alone, which took us just over 70 hours, would have taken much longer using stone tools. (A short experiment 


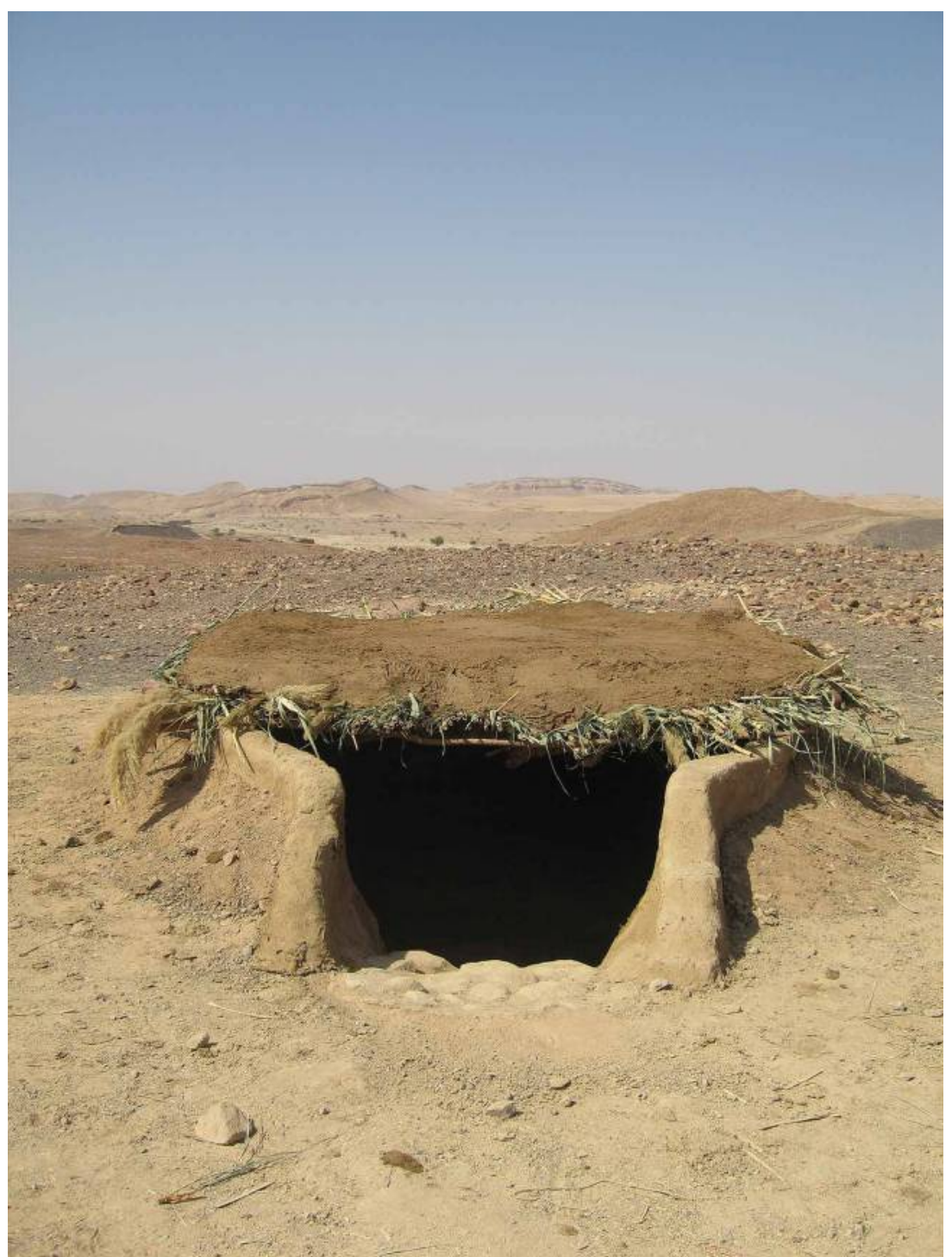

Figure 16 The finished structure in its surroundings (looking north-west). The mud-covered roof is clearly visible.

with a stone maul, similar to those found on site, indicated it would have been hard work getting through the gravel of the knoll.) Another example is the mining and transporting of sediment to the site, which took in this case around 100 hours, less than a fifth of the total time (Table 1). Unless suitable sediment was present on or very near to the site, this would have taken much more time in the past. Digging sediment without metal tools and transporting it, presumably by carrying it in containers such as baskets or leather bags, would have taken a long time and would have been heavy work (depending on the type of sediment, distance and slope, weather and motivation; Erasmus (1965) reports that as much as over $2 \mathrm{~m}^{3}$ of sediment, or a third of what we used in total, could be dug by one person with a digging stick and carried by another over $100 \mathrm{~m}$ in 6 hours. It is, however, unlikely that this would be possible with the extremely dry and hard, compact sediment in the Wadi Faynan area). It is of course possible that the sediment recovered when the pit was being excavated was used. This does not seem very likely as the natural deposits are very gravelly. In the walls at WF16 no such amounts of gravel were found, and the sediment from the site itself would therefore have had to be sieved. Moreover, the pisé of WF16 appears too clean to have been made using re-cycled construction and occupation material if the pit was excavated into earlier cultural deposits.

The wadi floor was not so deeply incised in the PPNA and the stream would have run closer to the site, but it would require a lot of travelling up and down to transport the $c .3000$ litres of water to the site in suitable containers. If the mud mix was made 
beside the wadi, this very heavy mix would have had to be transported up, and it is therefore likely that the mud was mixed at the site.

The work required was perceived as very heavy by the team, comprising experienced archaeological excavators and Bedouin. All aspects involved heavy manual labour: the sediment to mine was often dried out and compact, and mixing the pisé ingredients together was labour intensive. It is possible that in the past more water would be added to the mix, making the mixing process easier, leaving it to dry until the right consistency was reached (as in Thomas 2005). Nonetheless, that would still require heavy physical labour, and, in addition, the transport of more water.

This minimum amount of labour input has clear implications for the construction of the several larger structures at WF16, such as $\mathrm{O} 45(5.5 \mathrm{~m} \times 4.2 \mathrm{~m})$, and especially $\mathrm{O} 75$. The latter structure measures $22 \mathrm{~m} \times 19 \mathrm{~m}$ and has mud-plastered floors and a mud-plastered bench (Finlayson et al. 2011b: 8184; Mithen et al. 2011: 354). While it would perhaps have been possible, although hard work, to construct a smaller building such as the replica structure with a small group of people in several weeks, the larger structures would have required a larger, presumably communal effort, as well as a greater degree of organization. The work effort put in suggests a commitment to the place; this commitment is further suggested by the need to stay for a prolonged period of time at the site in order to allow the pisé layers to dry before a new layer could be added.

\section{Function}

When finished, the structure provided a cool and shady place, even though the roof did not completely cover the interior. With the cup-hole mortar in the middle, it is difficult to find enough space to stretch out to sleep, especially for more than one or two people. As discussed above, it is likely that the entrance would have been very small, not allowing for an easy in- and outflow of people. Therefore, the space does not appear to support the idea that a nuclear family would have lived in it, and it may rather have been a place for activity, presumably involving the mortar, in the shade, and/or storage at some point during the year (see also Flannery 2002).

After the structure had dried out for a couple of weeks, it was possible to stand on the roof. If indeed the roofs were flat as the evidence suggests, they could provide an activity area. This is also confirmed by chipped-stone fragments found on the surface of collapsed roof segments of Structure O45 at WF16.
The experimental building therefore shows the possibility of the structure as a multi-purpose environment.

\section{Wider implications}

The results of the experimental construction based on a WF16 pit building have several implications for our understanding of the role of architecture at WF16 and in the Near Eastern PPNA. Firstly, even though labour input cannot be exactly reconstructed, it is clear that a considerable effort would have gone into building earthen structures. This heavy work, with the additional requirement to frequently return to, or stay over a longer period at the building site, which required commitment to a place and a certain amount of organization. This is especially the case for the building of larger structures, but also for the simultaneous (re)building of several smaller structures (see Finlayson et al. 2011b). Except for implications for increased sedentism, this corresponds with wider evidence for a sense of community in the PPNA, such as the presence of 'communal buildings' at, for example, Jerf el Ahmar and Mureybet (Stordeur et al. 2000), and communal storage structures as at Dhra' and WF16 itself (Finlayson et al. 2011a).

Secondly, the conclusions about the function of the structure have implications for how we reconstruct the organization of PPNA society. The experimental structure is clearly too small to comfortably sleep more than one or two people, especially with the mortar set into its floor. It is also not very easy to enter or leave the structure, and it would have been harder with the smaller opening that the PPNA structure probably had. Taking into account that cultural perceptions of space differ, it is nonetheless very unlikely that such a small building would have functioned as simply a dwelling of a household, as such structures have been traditionally interpreted (e.g. Banning 2003; Watkins 1990; see the discussion in Finlayson et al. 2011a). Rather, the structure appears to represent a multi-purpose environment including a function related to the cup-hole mortar (Finlayson et al. 2011a). This is in agreement with the overall lay-out of WF16, where one very large structure is present with other structures ranging in size from $c .6 \mathrm{~m}$ in diameter to very small, at least some of which appear to have specific functions (Finlayson et al. 2011a; 2011b). We have interpreted this as indicating a level of community organization, with little indication that individual buildings served as houses for nuclear families (Finlayson et al. 2011b). This experimental work provides more support for this conclusion. 
While much variation exists between different PPNA sites, WF16 is not an exception in this respect. At many other PPNA sites, especially in the earlier phases, at least several of the structures are of a similar small size as the experimental structure presented in this paper (Finlayson et al. 2003a; see Hemsley 2008; Kozlowski and Kempisty 1990; Noy 1989; Noy et al. 1973; Samzun et al. 1989). As suggested by Flannery (2002), and now confirmed by the construct, this is simply too small to serve as a house for a nuclear family unit. This has important implications for interpreting the Neolithic, but it is beyond the scope of this paper to discuss these in more detail (but see for example Finlayson et al. 2011a; 2011b).

It has recently been argued that the term 'household' should not automatically be applied to the Neolithic and that instead the use of such terms should be based on evidence (Düring and Marciniak 2006; Finlayson et al. 2011a). Such evidence is mainly provided by the archaeological record (e.g. Hemsley 2008), but it is hoped that this paper has shown that experimental archaeology can also be very informative.

\section{Conclusion and future research}

In Wadi Faynan an informative construct was built based on a PPNA semi-subterranean earthen structure from WF16. Sediment, water, reeds and wood were derived locally. Cereal straw and chaff came from further away, but suitable vegetation can be found close to the site, especially in spring and early summer, and is expected to have been more abundant during the PPNA. Therefore, all the required material is believed to have been locally available for the inhabitants of WF16.

The construction method in general worked well. We intend to continue to test its similarity to the original methods used at WF16 by analyzing the modern structure to compare it with the archaeological structures already examined. The multiple-laying of wet mud appears to be the method by which the WF16 walls had been built. The observation at WF16 of stepped walls might indicate that similar problems with drying mud were encountered in the past as was the case with the experimental construction. The construction of a flat roof worked well and provided a solid work space on top of the roof. The only construction feature that diverged from archaeological data was the floor, which at WF16 had probably been laid in several thinner layers instead of the one thick layer used for the construct.
Building a pisé structure by applying wet mud mixture proved to be both labour intensive and physically demanding, requiring a team of on average six people for almost three weeks to complete a small structure. Much more time would have been needed in the PPNA, mainly to dig and transport material without the modern tools and transport that we utilized. The labour required to construct such a small building has clear implications for the interpretation of the larger buildings at WF16, which would have required a substantial, communal effort.

One of the challenges of the experimental construction was to combine research and public objectives. Although a few concessions had to be made, mainly due to limited time available, the public outreach and experimental archaeology aims were well integrated, with a finished structure that both helps to visualize PPNA life for the visitor to Wadi Faynan, and provides valuable information about the (possible) construction methods of PPNA buildings. It has confirmed that the traditional interpretation - that PPNA structures served as houses for nuclear families - should be questioned.

The structure is being regularly monitored for signs of decay and infill, such as cracks in the walls and roof, washing off of mud from the walls onto the floors and outside surface, possible sagging of the roof, and accumulation of sediment on the floor. This ongoing monitoring of the building will give valuable information on the processes of decay and collapse which will enhance interpretation of the WF16 archaeological remains.

\section{Acknowledgements}

The WF16 project $2008-10$ was funded by the Arts and Humanities Research Council (AH/E006205/1) and was directed by Bill Finlayson, Steven Mithen and Mohammad Najjar. We thank the Department of Antiquities of the Hashemite Kingdom of Jordan for permission to build the structure and for assistance with building it. We are very grateful to all members of the team who undertook the hard work of building the house: Catherine Douglas, Nick Pankhurst, Ben Sharp and Dan Wheeler; to DoA representative Nail Themer; to Paul Burtenshaw for coming to help us for a several days; and to various members of the Bedouin community. Finally, we thank the two anonymous reviewers and the Editor for their useful comments.

\section{References}

Akkermans, P. M. M. G. and Schwartz, G. M. 2003. The Archaeology of Syria. From Complex Hunter-Gatherers to Early Urban Societies (ca. 16,000-300 BC). Cambridge: Cambridge University Press. 
Banning, E. D. 2003. Housing Neolithic farmers. Near Eastern Archaeology 66: 4-21.

Bar-Matthews, M., Ayalon, A., Gilmour, M., Matthews, A. and Hawkesworth, C. 2003. Sea-land oxygen isotopic relationships from planktonic forminifera and speleothems in the Eastern Mediterranean region and their implication for paleorainfall during interglacial intervals. Geochimica et Cosmochimica Acta 67: 3181-99.

_, Ayalon, A. and Kaufman, A. 1997. Late Quaternary paleoclimate in the Eastern Mediterranean region from stable isotope analysis of speleothems at Soreq Cave, Israel. Ouaternarv Research 47: 155-68.

—, Ayalon, A., Kaufman, A. and Wasserburg, G. J. 1999. The Eastern Mediterranean paleoclimate as a reflection of regional events: Soreq cave, Israel. Earth and Planetary Science Letters 166: 85-95.

Bar-Yosef, O. 1995. Earliest food producers-Pre-Pottery Neolithic (8000-5500 BP). In, Levy, T. E. (ed.), The Archaeology of Society in the Holy Land: 190-204. London: Leicester University Press.

Cauvin, J. 1977. Les fouilles de Mureybet (1971-1974) et leur signification pour les origines de la sédentarisation au Proche-Orient. Annual of the American Schools of Oriental Research 44: 19-48.

Cappers, R. T. J. 2006. The reconstruction of agricultural practices in ancient Egypt: an ethnoarchaeobotanical approach Palaeohistoria 47/48: 429-46.

Damluji, S. S. 1992. The Valley of Mud Brick Architecture. Shibam, Tarim and Wadi Hadramut. Reading: Garnet Publishing.

Dennis, S. 2003a. The experimental reconstruction of a Pre-Pottery Neolithic B structure at Beidha - a visual introduction. Levant 35 39-48.

- 2003b. PhD dissertation project: the use of experimental archaeology to explain and present Pre-Pottery Neolithic architecture at Beidha in Southern Jordan. Neo-Lithics 2(3): 37-38.

- 2008. The Use of Experimental Archaeology to Examine and Interpret Pre-Pottery Neolithic Architecture: A Case Study of Beidha in southern Jordan. Ph.D. University of Edinburgh.

_, Finlayson, B. and Najjar, M. 2002. Conservation and preservation of Neolithic Beidha, southern Jordan. Antiquity 76: 933-34.

Doat, P., Hays, A., Houben, H., Matuk, S. and Vitoux, F. 1979. Construire en Terre. CRAterre, Collection AnArchitecture. Paris Editions Alternatives et Paralleles.

Düring, B. S. and Marciniak, A. 2006. Households and communities in the central Anatolian Neolithic. Archaeological Dialogues 12(2): $165-87$.

Elliott, S. 2010. Wadi Faynan, Southern Jordan, multi-method sedimentary analysis and micromorphological assessment. AFESS report, University of Reading.

- 2011. Second WF16, Wadi Faynan, Southern Jordan, multi-method sedimentary analysis and micromorphological assessment QUEST report, University of Reading.

Emery, V. L. 2011. Mud-brick architecture. In, Wendrich, W. (ed.), UCLA Encyclopedia of Egyptology. Los Angeles. http://escholar ship.org/uc/item/4983w678 (last accessed 02/07/2013).

Erasmus, C. T. 1965. Monument building: some field experiments Southwestern Journal of Anthropology 21: 277-301.

Facey, W. 1997. Back to Earth. Adobe Building in Saudi Arabia. Riyadh: Al-Turath.

Fathy, H. 1989. Architecture for the poor, and experiment in rural Egypt. Cairo: The American University in Cairo Press.

Finlayson, B., Kuijt, I., Arpin, T., Chesson, M., Dennis, S., Goodale, N. Kadowaki, S., Maher, L., Smith, S., Schurr, M. and McKay, J. 2003a. Dhra', excavation project, 2002 interim report. Levant 35: $1-38$.

-, Kuijt, I., Mithen, S. and Smith, S. 2011a. New evidence from Southern Jordan: rethinking the role of architecture in changing societies at the beginning of the Neolithic process. Paléorient 37: $123-35$.

— and Mithen, S. J. (eds). 2007. The Early Prehistory of Wadi Faynan, Southern Jordan, Archaeological Survey of Wadis Faynan Ghuwayr and al-Bustan and Evaluation of the Pre-Pottery Neolithic Site of WF16. Oxford: Council for British Research in the Levant and Oxbow Books.

—, Mithen, S. J., Naijar, M., Smith, S., Maricevic, D., Pankhurst, N. and Yeomans, L. 2011b. Architecture, sedentism, and social complexity at Pre-Pottery Neolithic A WF16, Southern Jordan. Proceedings of the National Academv of Sciences 108: 8183-88.
—, Najjar, M. and Dennis, S. 2003b. Bayda: conservation and presentation project, April-November 2003. Annual of the Department of Antiquities in Jordan 47: 489-90.

Flannery, K. V. 2002. The origins of the village revisited: from nuclear to extended households. American Antiquity 67: 417-33.

Flohr, P. and Cappers, R. T. J. 2008. Akkers gearchiveerd in muren. Onderzoek naar Romeinse graanverbouw in Karanis (Egypte). Paleo-Aktueel 19: 125-34.

Friesem, D., Boaretto, E., Eliyahu-Behar, A. and Shahack-Gross, R. 2011. Degradation of mud brick houses in an arid environment: a geoarchaeological model. Journal of Archaeological Science 38: 1135-47.

Gebel, H. G. K. and Hermansen, B. D. 2004. Ba'ja 2003: summary on the 5th season of excavation. Neo-Lithics 2(4): 15-18.

Goodfriend, G. A. 1991. Holocene Trends in ${ }^{18} \mathrm{O}$ in land snail shells from the Negev Desert and their implications for changes in rainfall source areas. Quaternary Research 35: 417-26.

- 1999. Terrestrial stable isotope records of Late Quaternary paleoclimates in the eastern Mediterranean region. Quaternarv Science Reviews 18: 501-13.

Haberkorn, J. 2000. Ba'ja and Fersh: Bedouin architecture of the 20th century. Annual of the Department of Antiquities of Jordan 44: 142-44.

Hemsley, S. 2008. The Implications of Early Village Architectures: the Sensuous Geographies and Social Experience of the Near Eastern $P P N A$ and $P P N B$ Built Environments. PhD. University of Liverpool.

Horne, L. 1994. Village Spaces. Settlement and Society in Northeastern Iran. Washington: Smithsonian Institution Press.

Hunt, C. O., Elrishi, H. A., Gilbertson, D. D., Grattan, J., McLaren, S., Pyatt, F. B., Rushworth, G. and Barker, G. W. 2004. EarlyHolocene environments in the Wadi Faynan, Jordan. Holocene 14: 921-30.

Keefe, L. 2005. Earth Building: Methods and Materials; Repair and Conservation. London: Taylor \& Francis.

King, G. 1998. The Traditional Architecture of Saudi Arabia. London: I. B. Tauris Publishers

Kinzel, M. 2004. Some notes on the reconstruction of PPNB architecture. Neo-Lithics 2(4): 18-22.

Kozlowski, S. K. 1989. Nemrik 9, a PPN Neolithic site in Northern Iraq. Paléorient 15: 25-31.

- and Kempisty, A. 1990. Architecture of the Pre-Pottery Neolithic settlement in Nemrik, Iraq. World Archaeologv 21: 348-62.

Kuijt, I. and Finlayson, B. 2009. Evidence for food storage and predomestication granaries 11,000 years ago in the Jordan Valley. Proceedings of the National Academv of Sciences 106: 10966-70.

McHenry, P. G. 1984. Adobe and Rammed Earth Buildings. Design and Construction. New York: John Wiley \& Sons.

McLaren, S., Gilbertson, D. D., Grattan, J. P., Hunt, C. O., Duller, G. A. T. and Barker, G. A. 2004. Quaternary palaeogeomorphologic evolution of the Wadi Faynan area, southern Jordan. Palaeogeographv. Palaeoclimatology, and Palaeoecology 205: 131-54.

Mithen, S., Austen, P., Kennedy, A., Emberson, H., Lancaster, N. and Finlayson, B. 2007a. Early Neolithic woodland composition and exploitation in the Southern Levant: a comparison between archaeobotanical remains from WF16 and present-day woodland at Hammam Adethni. Environmental Archaeology 12: 49-70.

Mithen, S. J., Finlayson, B., Pirie, A., Smith, S. and Whiting, C. 2007b. Archaeological survey of Wadiis Faynan, Ghuwayr, Dana and alBustan. In, Finlayson, B. and Mithen, S. J. (eds), The Early Prehistory of Wadi Faynan: 47-114. Oxford: Council for British Research in the Levant and Oxbow Books.

- and Finlayson, B. 2007. The radiocarbon dates. In, Finlayson, B. and Mithen, S. J. (eds), The Early Prehistory of Wadi Faynan: 460-69. Oxford: Council for British Research in the Levant and Oxbow Books.

_, Finlayson, B., Smith, S., Jenkins, E., Najjar, M. and Maricevic, D. 2011. An 11600 year-old communal structure from the Neolithic of southern Jordan. Antiquity 85: 350-64.

Moquin, M. 2000. Adobe. In, Elizabeth, L. and Adams, C. (eds), Alternative Construction: Contemporary Natural Building Methods: 87-116. New York: John Wiley and Sons.

Newton, C. 2004. Plant tempering of Predynastic pisé at Adaïma in Upper Egypt: building material and taphonomy. Vegetation Historv and Archaeobotany 13: 55-64. 
Noy, T. 1989. Gilgal I-A Pre-Pottery Neolithic Site, Israel-the 1985-1987 seasons. Paléorient 15: 11-17.

—, Legge, A. J. and Higgs, E. S. 1973. Recent excavations at Nahal Oren, Israel. Proceedings of the Prehistoric Society 39: 75-99.

Purschwitz, C. and Kinzel, M. 2007. Ba'ja 2007. Two room and ground floor fills: reconstructed house-life scenarios. Neo-Lithics 2(7): 22-35.

Reynolds, P. J. 1999. The nature of experiment in archaeology. In Harding, A. F. (ed.), Experiment and Design. Archaeological Studies in Honour of John Coles: 156-62. Oxford: Oxbow Books.

Robinson, S., Black, S., Sellwood, B. and Valdes, P. J. 2011. A review of palaeoclimates and palaeoenvironments in the Levant and Eastern Mediterranean from 25,000 to 5,000 years BP: setting the environmental background for the evolution of human civilisation. In Mithen, S. and Black, E. (eds), Water, Life and Civilisation: Climate, Environment and Society in the Jordan Valley: 71-93. Cambridge: Cambridge University Press.

Rosen, A. 1986. Cities of Clay. The Geoarchaeology of Tells. Chicago: University of Chicago Press.

Samzun, A., Ronen, A., Philibert, D. and Lechevallier, M. 1989. Une occupation khiamienne et sultanienne à Hatoula (Israël)? Paléorient 15: 1-10.

Seeden, H. 1985. Aspects of prehistory in the present world: observations gathered in Syrian villages from 1980 to1985. World Archaeology 17: 289-303

Smith, M. 2000. Cob. In, Elizabeth, L. and Adams, C. (eds), Alternative Construction: Contemporary Natural Building Methods: 117-50. New York: John Wiley and Sons.

Smith, S., Wade, A., Black, E., Brayshaw, D., Rambeau, C. and Mithen, S. 2011. From global climate change to local impact in Wadi Faynan, southern Jordan: ten millennia of human settlement in its hydrological context. In, Mithen, S. and Black, E. (eds), Water, Life, and Civilisation: Climate, Environment and Societv in the Jordan Vallev: 218-44. Cambridge: Cambridge University Press.

Smith, W. 2003. Archaeobotanical Investigations of Agriculture at Late Antique Kom el-Nana (Tell el-Amarna). London: Egypt Exploration Society.

Spencer, A. J. 1979. Brick Architecture in Ancient Egypt. Warminster: Aris and Phillips.

Stone, P. G. and Planel, P. G. (eds). 1999. The Constructed Past. Experimental Archaeology, Education and the Public. London: Routledge.

Stordeur, D., Brenet, M., der Aprahamian, G. and Roux, J.-C. 2000. Les bâtiments communautaires de Jerf el Ahmar et Mureybet horizon PPNA (Syrie). Paléorient 26: 29-44.

Thanheiser, U. 1999. Plant remains from Kellis: first results. In, Hope, C. A. and Mills, A. J. (eds), Dakhleh Oasis Project: Preliminary Reports on the 1992-1993 and 1993-1994 Field Seasons: 89-93. Oxford: Oxbow Books.

Thomas, G. D. 2005. The Prehistoric Buildings of Chalcolithic Cyprus; the Lemba Experimental Village. BAR International Series 1444. Oxford: Archaeopress.

van der Veen, M. 2001. The botanical evidence. In, Maxfield, V. A. and Peacock, D. P. S. (eds), Mons Claudianus, Survey and Excavation 1987-1993: 175-48. Cairo: Institut Français d'Archéologie Orientale.

Watkins, T. 1990. The origins of house and home? World Archaeology 21(3): 336-47.

Watson, P. J. 1979. Archaeological Ethnography in Western Iran. Tucson: University of Arizona Press.

Willcox, G. and Fornite, S. 1999. Impressions of wild cereal chaff in pisé from the 10th millennium uncal B.P. at Jerf el Ahmar and Mureybet: northern Syria. Vegetation History and Archaeobotany 8: 21-24. 